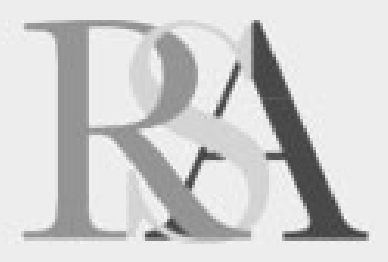

The Impact of the Netherlandish Landscape Tradition on Poetry and Painting in Early Modern England

Author(s): Sara Trevisan

Source: Renaissance Quarterly, Vol. 66, No. 3 (Fall 2013), pp. 866-903

Published by: The University of Chicago Press on behalf of the Renaissance Society of America

Stable URL: http://www.jstor.org/stable/10.1086/673585

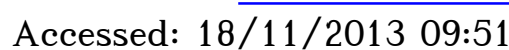

Your use of the JSTOR archive indicates your acceptance of the Terms \& Conditions of Use, available at

http://www.jstor.org/page/info/about/policies/terms.jsp

JSTOR is a not-for-profit service that helps scholars, researchers, and students discover, use, and build upon a wide range of content in a trusted digital archive. We use information technology and tools to increase productivity and facilitate new forms of scholarship. For more information about JSTOR, please contact support@jstor.org.

The University of Chicago Press and Renaissance Society of America are collaborating with JSTOR to digitize, preserve and extend access to Renaissance Quarterly. 


\title{
The Impact of the Netherlandish Landscape Tradition on Poetry and Painting in Early Modern England*
}

\author{
by SARA TREVISAN
}

\begin{abstract}
The relationship between poetry and painting has been one of the most debated issues in the history of criticism. The present article explores this problematic relationship in the context of sixteenthand seventeenth-century England, taking into account theories of rhetoric, visual perception, and art. It analyzes a rare case in which a specific school of painting directly inspired poetry: in particular, the ways in which the Netherlandish landscape tradition influenced natural descriptions in the poem Poly-Olbion $(1612,1622)$ by Michael Drayton (1563-1631). Drayton - under the influence of the artistic principles of landscape depiction as explained in Henry Peacham's art manuals, as well as of direct observation of Dutch and Flemish landscape prints and paintings - successfully managed to render pictorial landscapes into poetry. Through practical examples, this essay will thoroughly demonstrate that rhetoric is capable of emulating pictorial styles in a way that presupposes specialized art-historical knowledge, and that pictorialism can be the complex product as much of poetry and rhetoric as of painting and arttheoretical vocabulary.
\end{abstract}

\section{INTRODUCTION}

7 he relationship between poetry and painting is one of the most studies of this kind have been consistently riddled with methodological problems, mainly connected with the same questions: first of all, whether it can at all be ascertained that a piece of poetry was inspired by an actual painting; if so, whether a literary or an artistic approach should be used to analyze it; and finally, whether the subject of analysis is the product more of literary than visual sources, or of rhetorical rather than visual invention.

Several theories have been proposed to study the relationship between poetry and painting. It has been suggested, for instance, that even if it is not always possible to demonstrate whether a piece of poetry was inspired by a specific work of art, any correspondences between the two may be brought back to the general aesthetic principles of their own times. One exponent of

*I would like to thank Paul Taylor (Warburg Institute) for discussing with me issues concerning the Netherlandish landscape tradition, as well as two anonymous readers for $R Q$ for their invaluable criticism and suggestions. 
this theory is Mario Praz, who defines such mutual influence as an "air de famille ... between the expression of the arts in any given epoch of the past," and suggests a natural, if not inevitable, similarity between the fine arts of the same historical period. ${ }^{1}$

Some critics have taken sides and privileged the role of rhetoric. J. H. Hagstrum, for example, believes that Praz's method could lead to a vicious circular relation between poetry and painting, and to the search for a "spirit of the times" in which "individual artistic uniqueness tends to be neglected for the total uniqueness of the epoch." Literary pictorialism, Hagstrum states, is "more literary than pictorial," and while it may have had some relations to particular pictures or schools of painting, it does not necessarily have to have them, as in the long run it can develop conventions of its own. ${ }^{3}$

The importance of the pictorial dimension is upheld, among others, by J. B. Bender. He considers visual "patterns" as the basis of the relationship between poetry and painting, and focuses on the role of visual perception in the creation of pictorial, poetic images. Visual perception is, according to Bender, "a process of mediation between familiar schemata and confusing sensory experience": it is "a continuous synthesis of provisional interpretation, revision, and reinterpretation of ambiguous signals." "Therefore, poetry is ultimately pictorial, as "the poet engages his reader's imagination through artful, inevitably contrived, analogues of vision." "

Though aware of the difficulty in finding direct pictorial sources for a poetic passage, Lucy Gent tries to pin down what Bender calls "analogues of vision" through a study of sixteenth- and seventeenth-century art vocabulary. ${ }^{6}$ This is the basis for an attempt "to correlate what seems to be men's actual experience of seeing pictures with the formulae available to them for talking about painting." "7 Clark Hulse too believes that the elevation of poetry and painting to the status of liberal arts in the modern age, and their subsequent theorization, brought forward the creation of a shared knowledge that constitutes the vocabulary for discussing their mutual relationship. ${ }^{8}$ Hulse stresses the importance of the connection between painting terminology and the aesthetic experience, when he says that " $[t] \mathrm{o}$ grasp the power of this artistic knowledge, we must understand not only its

${ }^{1}$ Praz, 24. See also Sypher, 1-18.

${ }^{2}$ Hagstrum, xiii-xiv.

${ }^{3}$ Ibid., xvi.

${ }^{4}$ Bender, 28.

${ }^{5}$ Ibid., 29.

${ }^{6}$ Gent, 3 .

${ }^{7}$ Ibid., 5 .

${ }^{8}$ Hulse, 16. 
content, but also the ways in which the very definition of artistic knowledge is shaped at any moment."

It is debatable, however, whether it is actually possible to analyze the relationship between poetry and painting as such, thus taking for granted that there must be only one. The varied cultural backgrounds of the authors under study complicates a single, consistent, and coherent theory of the interactions between poetry and painting, and in general, critics have acknowledged that it is difficult to establish whether poets and writers were influenced by actual paintings, or simply by "patterns, opinion, and vocabulary." ${ }^{\prime 10}$ René Wellek rejects the possibility of a general comparison of the arts on the basis of shared principles. Instead, Wellek advises, a safer way to proceed in the comparison between poetry and painting is to look at details, at "tangible works of art," moving "from the small to the large and from the particular to the general." aside "brilliant generalizations," and starting with "precise and fully documented investigations." 12

Rather than deal with a general theory, this essay will follow Wellek's and Seznec's advice, and focus on the rare instance in which a specific school of painting directly inspired poetry: in particular, it will discuss the influence of the Netherlandish landscape tradition on natural descriptions in the poem Poly-Olbion by Michael Drayton (1563-1631). The argument will thoroughly demonstrate that rhetoric is capable of emulating pictorial styles in a way that presupposes specialized art-historical knowledge, ${ }^{13}$ and that pictorialism can be the complex product as much of poetry and rhetoric as of painting and art-theoretical vocabulary.

Poly-Obion is, in many ways, an original and idiosyncratic work in the history of English literature, being a 15,000-line poem on the topography

${ }^{9}$ Ibid.

${ }^{10}$ Gent, 3 .

${ }^{11}$ Wellek, 29-63; see also Farmer, 1-2.

${ }^{12}$ Seznec, 574. Studies on single authors, such as Sir Philip Sidney, John Donne, Robert Herrick, and Andrew Marvell, have been attempted: see Semler, 1998; Farmer.

${ }^{13}$ Weisstein, 23. The critic presents eight categorizations of poetic works that can be useful in the study of literary pictorialism: " 1 . Works of art which depict and interpret a story, rather than merely illustrating a text; 2. Literary works describing specific works of art (ekphrases, and Bild-, as distinguished from Ding-, gedichte); 3. Literary works constituting or literally re-creating works of art . . ; 4. Literary works emulating pictorial styles; 5. Literary works concerned with art and artists or presupposing specialized art-historical knowledge; 6 . Literary works using artistic techniques (montage, collage, the grotesque); 7. Synoptic genres (emblem); 8. Literary works sharing a theme, or themes, with works of art." 
and local history of all the counties of England and Wales. Drayton conceived his work as a poetic counterpart to recent topographical, cartographic, and antiquarian surveys, such as Britannia (1586) by William Camden (1551-1623), so much so that he introduced each Song with a map, and provided part 1 with learned, historical commentaries by the antiquarian John Selden. This "Herculean" work, ${ }^{14}$ as Drayton himself defined it, is a unique instance of topographical poetry on a large scale, a comprehensive description of the kingdom conceived for, and dedicated to, the "glorious and fortunate Starre" of the future king, Prince Henry Stuart (1594-1612)..$^{15}$

Drayton's "native," poetic Muse - the "spirit of the Place" — makes her way through England and Wales, pausing to listen to what the local landscape features, namely, the nymphs and personifications of mountains, valleys, rivers, and forests, have to say. ${ }^{16}$ From a poetic point of view, the overall structure betrays its debt to Spenser's "myth of locality," and ultimately to Ovid's Metamorphoses, versifying in pictorial lines the transformation of geographical elements into anthropomorphized or personified subjects, often within a pastoral setting. ${ }^{17}$ Sometimes the landscape elements tell the episodes of British history they have witnessed, or their "love stories" in the style of pastoral poetry; at other times they become engaged in conflicts or they utter complaints related to human history or to the interaction between man and landscape. In between these stories and also through them, Drayton's Muse peripatetically describes Britain's landscape and its topography, providing sketches of natural views from all English and Welsh counties.

Interesting for the purpose of this essay is not only Drayton's representation of the land of Britain, but also his use of the word landskip in its artistic sense, meaning a painting or work of art portraying a piece of

${ }^{14}$ Drayton, 1931-41b, 30:342.

${ }^{15}$ Ibid., $3^{*}$. By highlighting Drayton's indulgence in poetic pictorialism, this article has opted, unlike recent Poly-Olbion criticism, for a provocative privileging of aesthetics over politics, in order to reflect on Drayton's poetic technique in the description of landscape, rather than his non-literary reasons for undertaking the project. There is a considerable amount of material on Poly-Olbion dealing with Drayton's patriotic, anti-Jacobean authorial intentions, his willingness "to make the land visible" in its "greatness" and its "particularity," and his power, as author, cartographer, and chorographer, to represent the national landscape in such a way that "[n]ot king, but country dominates his vision": Helgerson, 145, 140. For further discussion on Drayton's political intentions behind the writing of Poly-Olbion, see Revard; Ewell; McEachern, 138-91; Hadfield; Klein, 2001a; Klein, 2001b, 149-70; Adrian, 74-95.

${ }^{16}$ Drayton, 1931-41b, 1:8.

${ }^{17}$ Bender, 29-30; Gottfried, 108. 
land. ${ }^{18}$ It is one of the earliest occurrences of the term in English, and has not escaped scholars' attention. In English Taste in Landscape in the Seventeenth Century, Henry and Margaret Ogden state that Drayton's use of the term shows "an interest in landscape painting," although their opinion rests on the general assumption that Drayton's sources were literary rather than artistic. ${ }^{19}$ The Ogdens date the appearance of the term to the 1619 edition of Drayton's The Barons Wars (originally published in 1603), a historical poem set at the time of the Civil War during the reign of Edward II. However, in his unpublished doctoral dissertation, submitted in 1975, H. P. Duchemin correctly assigns Drayton's first use of the word landskip to the 1603 edition of The Barons Wars, and mentions its presence also in Poly-Olbion. Although he suggests a strong influence from artistic sources, he does not pursue the matter in depth. ${ }^{20}$

In Literature and the Visual Arts in Tudor England, David Evett observes that Poly-Olbion betrays an awareness of artistic theories of landscape painting. He notices Drayton's clarifying definition of landskip in a marginal note to Song 18, and refers to the first occurrence of the term in Poly-Olbion as "the first recorded English use of the word landscape in connection with an actual scene": Evett, however, takes no notice of the other two occurrences in Poly-Olbion, nor does he attempt a visual analysis. Like the Ogdens, he connects Drayton's landscape depictions "more to reading than to observation." 21 In her Picture and Poetry 1560-1620, Gent briefly mentions Drayton's interest in landscape. She states that in the late 1590s Drayton was "naive" and "enthusiastic of pictorial effects," an attitude at which the poet would look back with embarrassment in the early seventeenth century. ${ }^{22}$

As will be shown in the course of this essay, Drayton's use of the word landskip reveals that some of the poetic descriptions in Poly-Olbion reflect the art theory and practice of sixteenth- and seventeenth-century Dutch and Flemish landscape depictions, and it testifies to Drayton's interest in the visual arts, and to his will to integrate artistic landscapes into his verse. Poetic rhetoric can thus be seen at work under the influence of art vocabulary and of visual perception as determined by artistic technical rules. The first section

\footnotetext{
${ }^{18}$ For the sake of clarity the term landscape will be used to refer to a tract of land, and landskip to refer to a painting or other work of art portraying a piece of land, even if, in the sixteenth and seventeenth centuries, landskip was sometimes used to refer to both.

${ }^{19}$ Ogden and Ogden, 1955, 25.

${ }^{20}$ Duchemin, 463-64.

${ }^{21}$ Evett, 168-69.

${ }^{22}$ Gent, 22. Ibid., 12, also writes, with a chronological contradiction, that Drayton's interest in landscape was perhaps fostered by his antiquarian friend, Edmund Bolton (1575-1633), around 1610 .
} 
of the essay will discuss the presence of Dutch and Flemish landscape paintings and prints in England, and the importance of such artifacts to the diffusion of the principles of landscape depiction; it will then provide instances of early uses of the word landskip in English and define the background of Drayton's linguistic choice. The second section will analyze Drayton's rhetorical elaboration of the theory and practice of landscape depictions, weighing possible sources and the degree to which Netherlandish pictures shaped Drayton's verse.

\section{THE ART AND RHETORIC OF LANDSKIP IN SiXteenth- And SEVEnteEnth-Century England}

There is little evidence regarding the diffusion of landscape painting in England between 1560 and 1620, with almost no documentation on holdings by members of the middling ranks, and few reliable inventories from private aristocratic collections. ${ }^{23}$ No such pictures are recorded as having been acquired by English noblemen before the end of the sixteenth century, ${ }^{24}$ and good-quality works of art, including Dutch and Flemish ones, were more often present in the collections of wealthy aristocrats, to which few people had access. ${ }^{25}$ In England it was easier to find depictions of landscapes as a background to narrative scenes of a mythological, religious, or popular subject: landskip was in fact considered an adjunct to a painting, something, as Henry Peacham (1546-1634) wrote in the first printed art-theory manual in English, that is "seldome ... drawne by it selfe, but in respect $\&$ for the sake of something els. ${ }^{, 26}$ It was only in the $1630 \mathrm{~s},{ }^{27}$ when landscape painting had come to be recognized as an independent genre, that the first specialized Dutch and Flemish landscapists were hired at the court of Charles I ${ }^{28}$ and their works,

${ }^{23}$ See Ogden and Ogden, 1955, 16-19.

${ }^{24}$ Hayes, 38.

${ }^{25}$ Gent, 32. Gent's assumption does not take into account that, as happened in the Netherlands, merchants and traders could have afforded small landscape paintings. Unlike in the case of the Netherlands, however, there is no solid research on the topic in England.

${ }^{26}$ Peacham, 1606, 28. For a theory of the development of landscape as a genre in its own right, see Gombrich, 1966; Cosgrove. For general discussions on the development of landscape painting on the Continent, see Wood; Lagerlö;; Silver; Prosperetti.

${ }^{27}$ Dunthorne, 41 .

${ }^{28}$ Sluijter, 19. For specific landscape paintings in the collection of Charles I, see Millar. It should be noted that landskip was a term that could also refer to perspective in pictures representing places seen through a large prospect, as the words perspective and prospect(ive) were considered synonyms. So, even an architectural background with no vegetation could still be considered a landskip: see Turner, 292. 
together with those of Northern and Flemish painters, began to occupy a substantial proportion of English private collections. ${ }^{29}$

Nevertheless, dozens of artists from the Netherlands - where an early tradition of landscape painting had developed - had moved to England during the late 1560s and the early 1570s, due to the persecution of Protestants in the Low Countries. ${ }^{30}$ The most renowned were Hans Eworth (ca. 1520-74), Marcus Gheeraerts father (1520-90) and son (1561/62-1636), and Joris Hoefnagel (1542-1600). Their style became so fashionable in England that noble families and royalty began to ask for their portraits to be painted by Flemish artists only. ${ }^{31}$ Although some of these artists painted the most important portraits of Queen Elizabeth, James I and his family, and those of many other aristocrats, they are not known to have worked on a consistent and continuous production of landskips. ${ }^{32}$ Only a couple of such examples have survived from the time of Elizabeth I, as isolated works of a topographical nature. In 1562 the Flemish painter Anthonis van den Wyngaerde (1525-71) produced a view of Greenwich and the Panorama of London, one of the earliest surviving prospects of the city. ${ }^{33}$ In $1569-70$ Hoefnagel painted the Fête at Bermondsey, a topographical view in the style of Paul Bril (1554-1626) and Pieter Bruegel the Elder (1525-69), with the Tower of London in the background. ${ }^{34}$ Landscape was still an uncommon subject, and it would not stir any subsequent imitations until the early seventeenth century. ${ }^{35}$ However, George Vertue (1684-1756) and Horace Walpole (1717-97) tell us that Marcus Gheeraerts the Elder, who had fled from Flanders to London in 1568, was also good at landscape depictions: the only extant such work by Gheeraerts is the engraving of a bird's-eye view of Bruges from 1562. ${ }^{36}$

${ }^{29}$ For a detailed list and analysis of such collections, the most important of which were those of the Earl of Arundel and the Earl of Buckingham, see Ogden and Odgen, 1955, 16-19, 30-35. Unfortunately, once again, these inventories refer to big collections only: no evidence is given about smaller ones.

${ }^{30}$ Maartens and Peeters, 38. For the purpose of this article the Italian landscape tradition in England will not be considered.

${ }^{31}$ Wells-Cole, 233. The Dutch art theorist Karel van Mander highlighted how, in the 1580s, it became fashionable for the English nobility to have portraits made by Netherlandish artists: quoted in Sluijter, 14.

${ }^{32}$ Rubinstein, 166.

${ }^{33}$ Wilks, 41.

${ }^{34}$ Waterhouse, 28.

${ }^{35}$ Hearn, 1995, 113. Grant, 1:31-32, also mentions a watercolor with a view of Windsor Castle from the park, drawn in a Bible by Edward VI in 1538, and including trees and animals.

${ }^{36}$ Vertue, 1931-32, 94, 108; Walpole, 1:165. 
Hoefnagel's view of Bermondsey constituted the beginning of what would become in the 1630s a successful tradition of English topographical landscape depictions, mostly mastered by Dutch and Flemish artists. ${ }^{37}$ As Greg Rubinstein suggests, in the second half of the sixteenth century and the early seventeenth century, "it is in the areas where landscape merges into other genres of painting that many of the most interesting and uniquely Anglo-Dutch pictures are to be found," a fusion that highlights the "complex relationship between topographical and imaginary modes of landscape representation" typical of the English context. ${ }^{38}$ Although none of the two-dozen Netherlandish artists at the Jacobean court were active landscapists, they tended to pay more attention to ornamental landscapes than other painters in Holland and Flanders. ${ }^{39}$ An instance of this is a painting by Paul van Somer (1577-1621), who was in England in the late 1610s, after leaving Antwerp: it depicts Queen Anne in hunting clothes, with a vista of the palace of Oatlands in the background..$^{40}$ Anne's son, Henry, Prince of Wales, possibly owned some Dutch or Flemish landskips. In 1610 he received a gift from the Dutch ambassadors, including, at his special request, paintings by Dutch masters. Two seascapes celebrating Henry's passion for the sea - a storm by Julius Porcellis (1610/19-45) and a sea battle by Hendrick Vroom (1562-1640) - are the only two pictures for which some evidence is extant. ${ }^{41}$

So most of the few landscape paintings produced in England from the mid-sixteenth to the early seventeenth century were topographical views, pictorial elaborations of the kind of townscapes that the English court had commissioned since the time of Henry VIII. ${ }^{42}$ As in the Netherlands, in England the production of maps, topographical views, and landskips had been connected with one another. Maps were engraved and reproduced as prints or book illustrations, and artists working on engraved landskips and topographical views often crossed paths with the developing cartography in

\footnotetext{
${ }^{37}$ Sluijter, 19.

${ }^{38}$ Rubinstein, 166.

${ }^{39}$ Ibid.

${ }^{40}$ See Millar, 5 (\#21); Strong, 26-27.

${ }^{41}$ Van Gelder. Henry's attraction to Netherlandish painting in particular surfaces from his unsuccessful attempt in 1611 to negotiate for the coming of the Dutch painters Miereveldt and Myten to London: Hearn, 2004, 227.

${ }^{42}$ In Henry VIII's collection there were townscapes, among others, of Antwerp, Paris, Florence, the Holy Land, and the whole world, which may have also had a practical function: Vertue, 1937-38, 4, 41; Walpole, 1:206. For the connection between surveying and artistic landscape painting, see Veltman.
} 


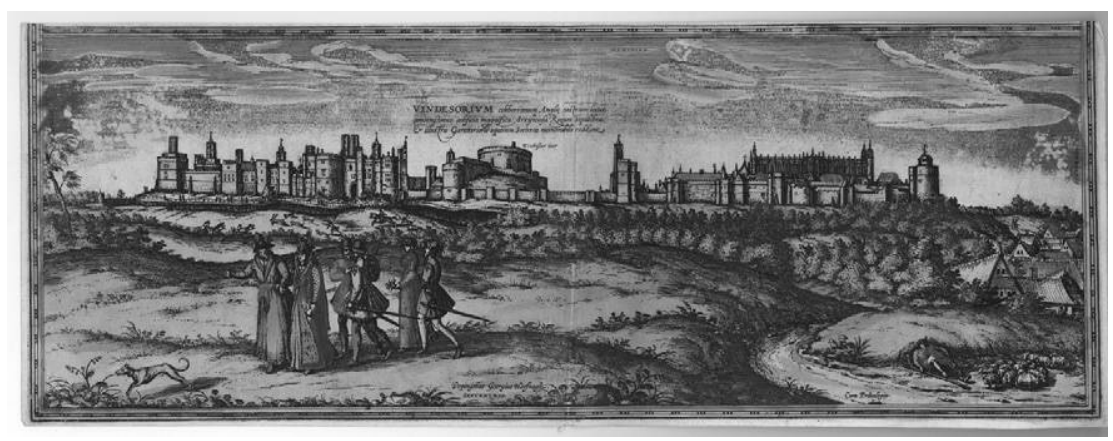

FIGURE 1. Joris Hoefnagel. Windsor, 1575. London, (C) The Trustees of the British Museum.

print. ${ }^{43}$ In 1572, for instance, when still in England, Hoefnagel produced some drawings of Windsor (fig. 1), Oxford, and Cambridge, later turned into engravings for Braun and Hogenberg's atlas, Civitates Orbis Terrarum (1572). ${ }^{44}$ In the same years, the Flemish Abraham Ortelius (1527-98) strengthened his connections with England, and with his atlas, Theatrum Orbis Terrarum (1570), inspired the creation of some of the most important instances of early English cartography: the Atlas of the Counties of England and Wales (1579) by Christopher Saxton (1540-1610), a map of Wales (1573) by Humphrey Llwyd (1527-68), and the maps in the antiquarian work Britannia by William Camden. ${ }^{45}$

Engravings and prints were essential to the diffusion of topographical and pictorial landscape views. ${ }^{46}$ Through prints, the Netherlandish landskip traveled throughout Northern Europe, sometimes as a genre in its own right (especially in the Netherlands), sometimes as an ornamental background to religious, mythological, or popular scenes. Such woodcut illustrations and engraved prints circulated in England from the mid-sixteenth century onward. For example, the painter Nicholas Hilliard (1547-1619), who also wrote a famous (though unpublished at the time) treatise, The Art of Limning (1573), may have seen prints by Albrecht Dürer (1471-1528). It was, however, from the 1590s on that a regular production of prints started in England. ${ }^{47}$

A pivotal figure in the English print trade was the Dutch publisher and printmaker Hans Woutneel (fl. 1586-1603), who moved to London in

\footnotetext{
${ }^{43}$ Hayes, 41.

${ }^{44}$ Rubinstein, 170.

${ }^{45}$ Llwyd's map, entitled Cambriae Typus, was first published as an appendix to Ortelius's atlas: Delano-Smith and Kain, 64, 67.

${ }^{46}$ Levesque, 4.

${ }^{47}$ Sluijter, 15.
} 
the 1570s. His most notable connection with the Netherlands was his collaboration, begun in the 1590s, with another Dutch publisher and engraver, Crispijn van de Passe the Elder (1564-1637), whose works he introduced to England. ${ }^{48}$ Woutneel distributed prints by the Plantijn press in Antwerp, which also dealt with de Passe's works. ${ }^{49}$ One of the Plantijn employees in the late sixteenth century was the printer and engraver Jan Sadeler I (1550-1600), who was also part of a family of printmakers. ${ }^{50}$ This is one example of an AngloDutch network that facilitated the circulation of prints, exchange of ideas, and mutual influence between English and Dutch engravers and printmakers.

The knowledge of such networks helps to explain the diffusion of Dutch and Flemish landskips in England. Through Woutneel, for instance, landskips engraved or printed by de Passe were most likely brought to London, including some, dated around 1599-1600, made after the work of Jan Brueghel the Elder (1568-1625). Between the 1575 and 1600, Jan Sadeler I printed and published four landskips by the Flemish Hans Bol (1534-93), originally produced in the 1560s. In the 1580s, he and his brother Aegidius I (1550-1609) reprinted scenes from the Old and New Testaments engraved by Bol, displaying complex landscape depictions (figs. 2-3). Thanks to these reprints, Bol's landskips would become very influential, and were much imitated at a European level. ${ }^{51}$ Around the 1610s, landscape prints by Sadeler and some by Dürer were circulating. ${ }^{52}$ Prints by Goltzius (1558-1617), including landskips (fig. 4), are recorded as having been present in private collections around the mid-1620s, ${ }^{53}$ whereas, in the mid-1630s, they were "commonly to be had in Popes-head-alley," in London, just like de Passe's prints. ${ }^{54}$

Engravings and illustrations for prints were also being produced in England. In London, Gheeraerts the Elder prepared etchings for Jan van der Noot's Het Theatre oft Toon-neel (1568), with landscapes in the background reminiscent of early sixteenth-century Netherlandish paintings. ${ }^{55}$ A similar Flemish style appears in the woodcuts prepared for The Shepheardes Calender (1579) (fig. 5), a poem by Edmund Spenser (1552-99), who, in 1569, had also translated Van der Noot's Theatre into English. The illustrations in The

${ }^{48}$ Veldman, 280; Griffiths, 14. Woutneel and de Passe famously coproduced a botanical book with beautiful prints entitled Altera Pars: see Gerard.

${ }^{49}$ Veldman, 280.

${ }^{50}$ De Ramaix, 70:1.1-2.

${ }^{51}$ Ibid., 4.13-29.

${ }^{52}$ Burton, 1621, 2:2.4.351.

${ }^{53}$ Burton, 1624, 2:2.4.233.

${ }^{54}$ Peacham, 1634, 128-29.

${ }^{55}$ Hind, 1:104-6. For a different theory on the author of these illustrations, see Friedland. 


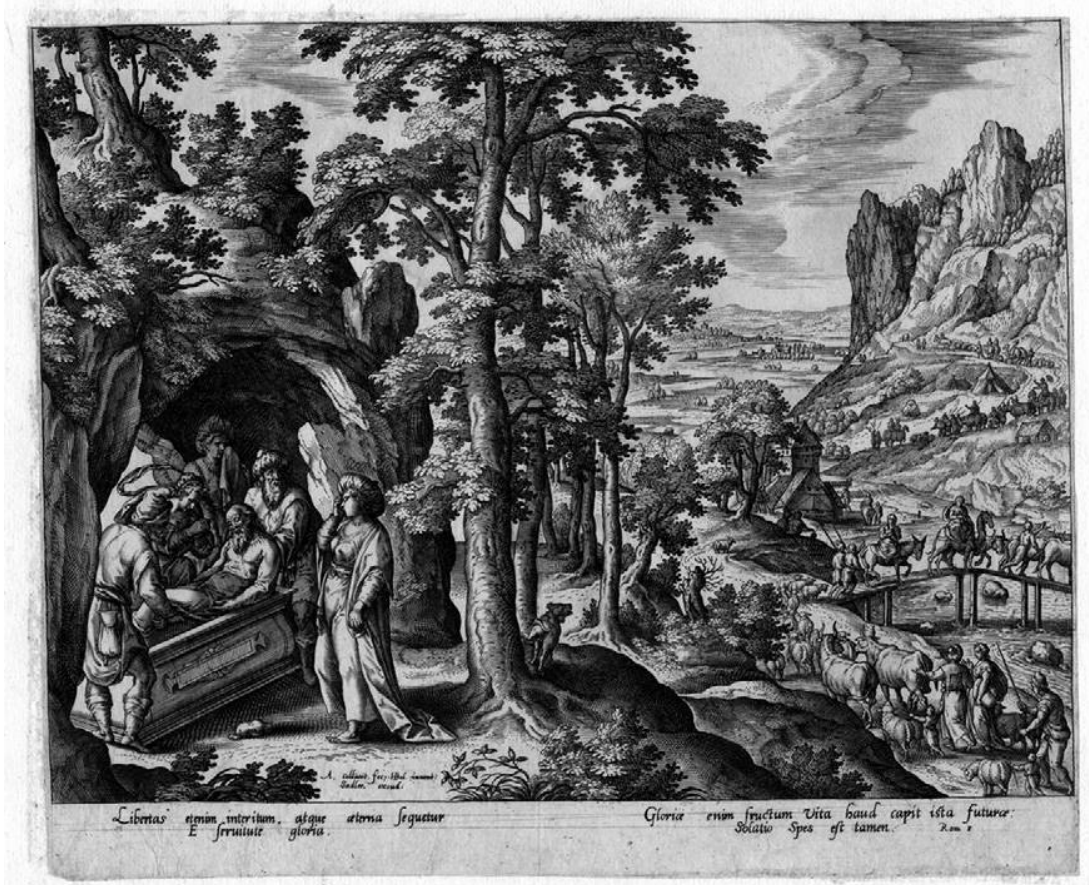

FIGURE 2. Hans Bol. The Burial of Jacob, ca. 1580-84. London, (C) The Trustees of the British Museum.

Shepheardes Calender resemble old-fashioned woodcuts for popular books, and present scenes showing monthly occupations, with a landscape behind. ${ }^{56}$ The depiction in print of seasonal and monthly traditional activities within a landscape demonstrates the frequency with which this topic was employed in paintings and engravings in the mid-sixteenth century. Because of the growing importance of background landscape depictions, representations of seasons and months can often be considered landskips in their own right. The figures in the foreground are set against a long prospect that can sometimes be compared to a landskip for its size and number of elements. Such pictures and prints are thus relevant to this study, as they may be "the earliest form in which landscape was widely known in England."

As for the very early years of the seventeenth century, the painter and writer Peacham has left a detailed account on the development of English art theory and taste. In his Art of Drawing with the Pen (1606), Peacham stresses

${ }^{56}$ Luborsky, 10 .

${ }^{57}$ Ogden and Ogden, 1955, 48-49. 


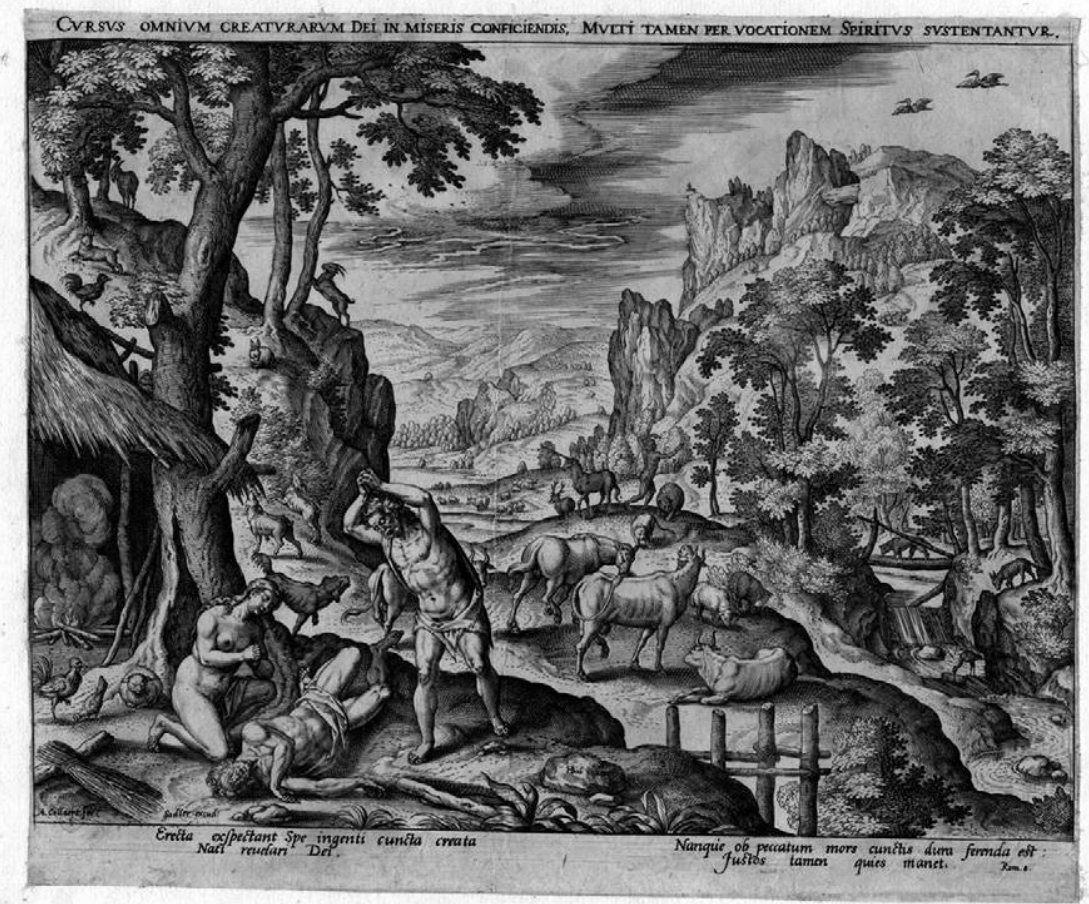

FIGURE 3. Hans Bol. Adam and Eve Discover the Dead Body of Abel, ca. 1580-84. London, (C) The Trustees of the British Museum.

the importance and excellence of Northern artists in landscape painting, but also their skilled pictorial organization of the subject. ${ }^{58}$ However, he still defines landscape as something that is "seldome ... drawne by it selfe, but in respect \& for the sake of some thing els." In the section on "shadowing," Peacham also mentions the excellence of prints by Goltzius and Stradanus (Jan van der Straet, 1523-1605), ${ }^{60}$ which likely included landscape depictions. In 1612 he published two works, Graphice, an enlarged edition of The Art of Drawing, and The Gentleman's Exercise, devised to educate the sons of aristocrats, encourage their passion for art and collecting, and turn them into good patrons. ${ }^{61}$ In both works the section on landskip is expanded, and shows Peacham's acknowledgement that landscape painting could be an

\footnotetext{
${ }^{58}$ Peacham, 1606, 28-31, 63. See Semler, 2004, 750.

${ }^{59}$ Peacham, 1606, 28.

${ }^{60}$ Ibid., 26.

${ }^{61}$ Levy, 175.
} 


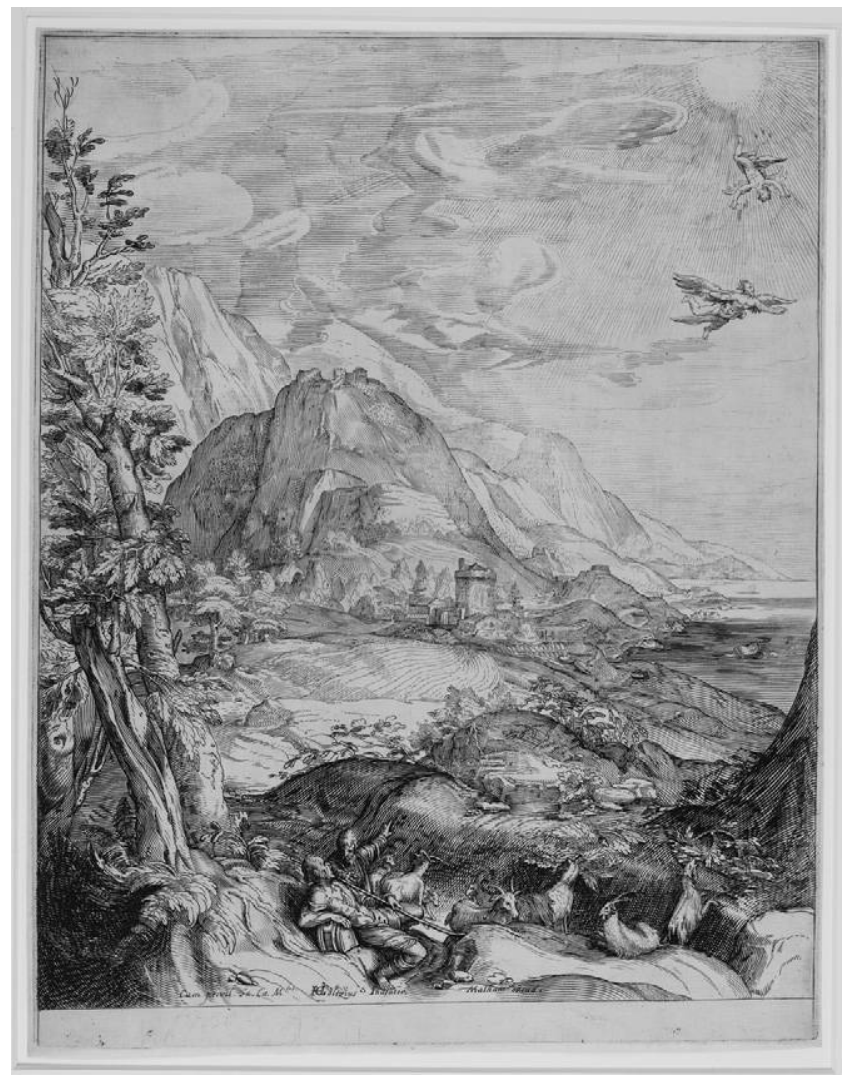

FIGURE 4. Hendrik Goltzius. Landscape with Daedalus and Icarus, ca. 1603. London, (C) The Trustees of the British Museum.

independent genre depicting, for instance, "the faire side of some goodly Citie, hauen, forrest, stately house with gardens . . . a countrey village, faire or market, Bergamascas cookerie, Morrice dancing, peasants together by the eare, and the like." ${ }^{\prime 2}$ This description suggests that he knew pictures in the Bruegelian tradition. ${ }^{63}$ Although he was never in the Netherlands before the end of $1612,{ }^{64}$ his reference to Goltzius and landscapes with daily occupations suggests that he possibly saw some of his landskips from the late 1590 s and early 1600 s. $^{65}$

\footnotetext{
${ }^{62}$ Peacham, 1612b, 44-45; Peacham, 1612a, 45.

${ }^{63}$ Levy, 183.

${ }^{64}$ Horden.

${ }^{65}$ Veldman, 193, 200.
} 


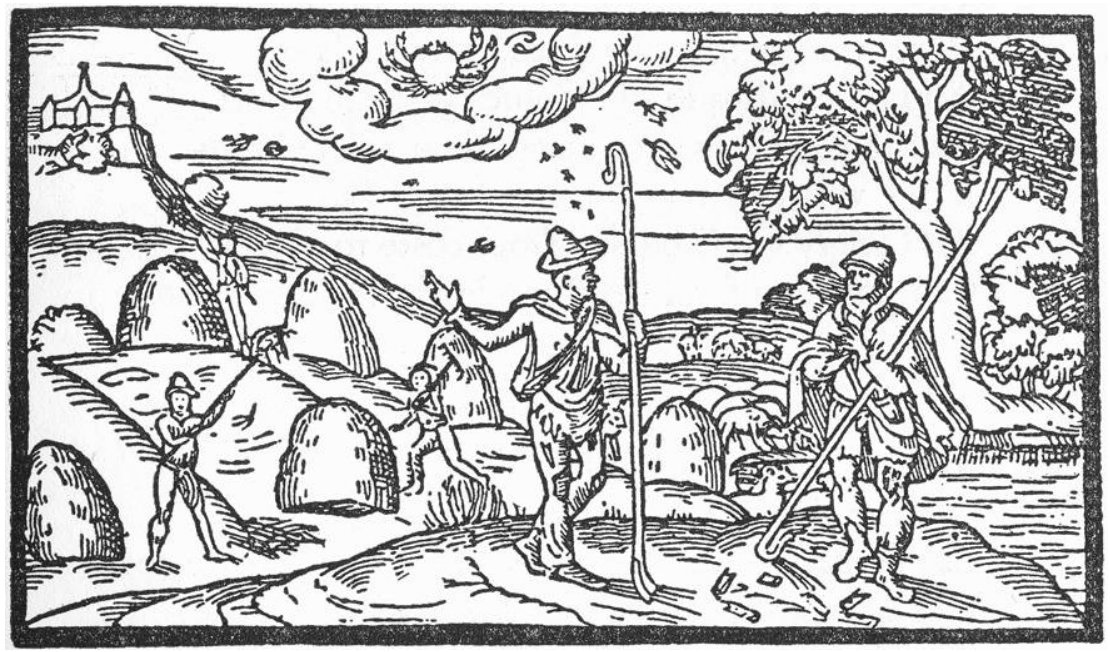

FIGURE 5. June, in Edmund Spenser, The Shepheardes Calender. London, 1579. Author's photograph.

Peacham employs the term landskip with its artistic connotation, which entered the English language only in the late sixteenth century. ${ }^{66}$ The first occurrence recorded in the $O E D$ is Richard Haydocke's rendition of the Italian word paesaggio in his Tracte Containing the Artes of Curious Paintings (1598), a translation of Giovanni Paolo Lomazzo's Trattato dell'arte della pittura (1584). ${ }^{67}$ Other manuscripts had been circulating in England since the late sixteenth century, providing painters with practical information on the drawing of landscape and spatial perspective. In the late sixteenth-

${ }^{66}$ According to the $O E D$ ("landskip in landscape, n."), in the sixteenth and early seventeenth centuries, landskip was used to indicate, "a picture representing natural inland scenery, as distinguished from a sea picture, a portrait, etc." (1.a, 1. $\beta$ ), and a similar "background scene in a portrait or figure-painting" (1.b); in general, "inland natural scenery, or its representation in painting" (3. $\alpha, 3 . \beta)$; or, figuratively, "a view, prospect of something" (4.a) and "a distant prospect: a vista" (4.b). In the words of Turner, 290, it is either a "painting of rural material ... often as a background or drollery, with no emphasis on structure or artistry," or a prospect, that is, "the expert representation of distant views (not necessarily of countryside) to create the illusion of realism and totality" — a meaning that contained also all the figurative uses of the word.

${ }^{67}$ It should be said, however, that Haydocke omitted altogether, for unknown reasons, the sixth book of the Italian edition, which focused on landskip. In Dutch, the first recorded (and printed) occurrence of the word landschap as referring to the subject of a painting is credited to the art theorist Karel van Mander, in his Schilder-boek (1604). See "landschap, n." (3.b) in Woordenboek der Nederlandsche Taal: http://gtb.inl.nl/?owner=WNT. 
century Short Treatise of Perspective, it is said that "of all kindes of Topiarie, Landskip's the cheefeste, which expresseth places of larger prospecte, as whole countries where the eye seemeth not to be hindred by any objectes ... either of nature or arte, but to passe as farre as the force thereofe can pierce." ${ }^{68}$ In 1606, in The Art of Drawing, Peacham gave the first definition of landskip in English, as "a Dutch word, \& it is as much as wee should say in English landship, or expressing of the land by hills, woodes, Castles, seas, valleys, ruines, hanging rocks, Citties, Townes, etc. as farre as may bee shewed within our Horizon." ${ }^{99}$

The term entered the world of literature around the same time. For instance, Thomas Dekker (ca. 1572-1632) mentions it in the dedication to his Seven Deadly Sins (1606). In this dedication, Dekker downplays his own work, a common rhetorical device. He states, through an artistic metaphor, that, though humble, his writing may nevertheless appeal and teach something to the reader, in the same way as "a Drollerie (or Dutch peece of Lantskop) may sometimes breed in the beholder's eye, as much delectation, as the best and most curious master-peece excellent in that Art." ${ }^{, 70}$ As paintings in their own right, Dutch landskips are hereby seen as lightweight subjects that scarcely resemble in quality and effect pieces of a more serious kind, such as histories and allegories. ${ }^{71}$ These textual examples show how the word landskip could be employed by literary authors to directly refer to art and to a visual depiction in painting of inland scenery: they suggest to readers, if only in vague terms, the form and content of the work of art.

Nevertheless, landscape descriptions also played a role in the field of English rhetoric: the skillful description of a natural view was an excellent way to demonstrate how good writing could emulate painting. And the first-ever reference to the word landskip in the English language dates back to 1586, twelve years before its appearance in Haydocke's translation. It is found in The English Secretorie by Angel Daye (fl. 1575-95), a rhetorical manual teaching "a perfect method, for the inditing of all manner of Epistles and familiar letters." ${ }^{72}$ In the section on "Epistles descriptorie," Daye compares the good

${ }^{68}$ British Library, Ms. Sloane 536, fols.1-22 (quoted in Ogden and Ogden, 1955, 2). See also Ogden and Ogden, 1947, 201.

${ }^{69}$ Peacham, 1606, 28.

${ }^{70}$ Dekker, dedication to Henry Fermor Esq.

${ }^{71}$ I hereby disagree with Turner when he says that the word landskip as referring to a "painting of rural material" implies no "emphasis on structure or artistry": Turner, 290. In this case, the point of the comparison is precisely the quality of the work of art.

${ }^{72}$ Gent, 10, 34, 73. This essay elaborates and extends Gent's observations. 
writer to a good painter who can "touche all thinges to the quick" while still providing a good, plain description of facts. ${ }^{73}$ The writer should follow the style of Daye's "curious painter," who, in drawing "a perfect peece of Lantskip," presents many things to the eye: "for wyth great admiration we doe there seeme to beholde, the most pleasaunt and goodely vallies: woodes hye, and decked with stately trees (some toppes thereof the winde seemeth to wreathe and turne at one side) then goodly rivers, hye wayes, and walkes, large situate and hie climing hills and mountaynes, far prospects of Cities, Steeples and townes, ships sayling on seas, and waves blown up aloft, the element cleere, fayre, and temperate, with some shining beames shadowing, and spreading over all these, wherein seemeth the delight so rare, and climate so perfect, as verye desire provoketh a man to gaze of it, as a thing in present life, and most certayne viewe." 74

The goodness of the landscape depiction depends on the quality of the verbal medium, which filters the visualization of the subject. A good painter, Daye says, can create a picture, or "peece," representing inland scenery, and make it look as if it were in front of the beholder's eyes. Daye's landscape description is at once pictorial and topographical, as if inspired by a bird'seye view gathered from recently published maps, like those in Saxton's Atlas. ${ }^{75}$ Daye's description uses the painter's achievement as a way to demonstrate what a letter writer should ultimately attain: "the very description and lively delivery [that] maketh us beeleve that our eye doth almost witnesse the same, and that our very sences are partakers of every delicacy in them contained." 76 The poetic depiction of landscape should emulate, if not equal, that produced through painting.

The principle behind this idea is the traditional rivalry between poetry and the visual arts. It originated in Plutarch's statements (attributed to Simonides) that "painting is mute poetry" and "poetry a speaking picture," and in the Horatian dictum ut pictura poesis, meaning both "as is painting so is poetry" and "as is poetry so is painting." 77 The common denominator in the ut pictura poesis idea is the concept of enargeia, or "descriptive vividness,"

${ }^{73}$ Daye, $43-44$.

${ }^{74}$ Ibid., 44.

${ }^{75}$ This may account for Daye's subsequent reference to the "learned Cosmographer," who shows "the unknown delights, situation, plentie and riches of countries whiche we never saw": ibid., 44-45.

${ }^{76} \mathrm{Ibid}$

${ }^{77}$ Lee, 197. 
as explained by Cicero and Quintilian, among others, and reprised by Erasmus in his De Copia. Descriptive vividness in poetry is "the power to paint clear images of the external world in the mind's eye as a painter would record them on canvas. ${ }^{178}$ Poetry can follow artistic principles, reproducing light and shadow and visual variety, while painting can follow rhetorical rules in the creation of specific elements and in the composition of the work of art. $^{79}$

Inspired by their classical and Renaissance counterparts, contemporary English rhetorical manuals discussed enargeia, and agreed with Daye that good descriptions should be "lively." Eloquence (1577), Peacham explains that "a description is when the Orator by a diligent gatherin together of circumstances, and by a fit and naturall application of them, doth expresse and set forth a thing so plainly and lively, that it seemeth rather painted in tables, then declared with words, and the mind of the hearer therby so drawen to an earnest and stedfast contemplation of the thing described, that he rather thinketh he seeth it then heareth it." ${ }^{81}$ Owing to his interest in painting and art theory, Peacham's words are even more telling. The rhetorical merit of a description depends on its degree of enargeia, or vividness. In order to achieve the latter, a writer should properly gather, select, and organize the various parts of a description so as to turn it into something the audience will perceive as "lively," as if it had been shown in visual form ("tables" meaning paintings). Descriptive vividness therefore rests in a limbo between the auditory and the visual. In De Inventione Dialectica (1479), an influential work in sixteenth-century England, ${ }^{82}$ Rudolf Agricola (1444-85) explains how, if the visual arts can convey verisimilar imitation by means of "things," that is, through the visualization of the subject matter with the help of nontextual tools, then poetry can only do it by means of "words," that is, through verbal amplification and the accumulation of details). It must

${ }^{78}$ Ibid., 198.

${ }^{79}$ Lunde, 53-54.

${ }^{80}$ As Mack, 2002, 76-77, 84-85, suggests, these manuals by Peacham and Daye, together with George Puttenham's Art of English Poesie (1589) and Thomas Wilson's Rule of Reason (1551), were printed over twenty times, and they can be considered "versions of a single archetext: the Renaissance English style manual." They share common classical sources for the treatment of figures and tropes - Rhetorica ad Herennium (particularly book 4), Quintilian's Institutio Oratoria (particularly books 8 and 9) - as well as humanistic treatises like Erasmus's De Copia.

${ }^{81}$ Peacham, 1577, 134-35.

${ }^{82}$ Howell, 49-50. 
achieve by verbal means the clarity of a visual rendition without the help of actual visualization. ${ }^{83}$

But good poets can also describe verbally by means of things, which is as close as they can get to the use of non-textual tools. Their poetic descriptions will thus be devised not through the use of the accumulation of specific details expressed by nouns referring to physical accidents of the elements described, but through the use of common nouns referring to semantic categories that must be as general as possible. Landscape is a very good example. If poets want to portray the natural world through things, they should describe in words what Peacham suggests English painters should do when drawing a landskip: "you must be very dainty in lessening your bodies by their distance and have a regard, the farther your Landsskip goeth to those universalia which as Aristotle saith (in respect of theyre particulars concealed from our sences) are notiora: as in discerning a building 10 or 12 miles off, I cannot tell whether it bee Church, Castle, gentlemans house, or the like: So that in drawing of it I must expresse no particular signe as belle, portculleis etc., but shew as weakly and as faintly as mine eie judgeth of it, because all those particulars are taken away by the greatnesse of the distance." ${ }^{84}$ In order to delineate a landskip, the poet should use the universalia of language common nouns - the semantic meaning of which must be as general as possible: he should avoid an excessive quantity of adjectives providing details that are impossible to perceive from the distance. The result will not be an ekphrastic description: ${ }^{85}$ the verse, in fact, will not describe any particular landscape painting as such, but will create a poetic landskip structured according to art-theoretical principles.

What Peacham would have considered an imperfect instance of his theories can be found in the True Description of Guiana (1617). Sir Walter Raleigh (1552-1618) describes a "Landskip of that excellent perfection, which no Art could better, hardly imitate." He mentions "the goodlinesse thereof, the brauery of the Hils, and comlinesse of the vallies, both shadowed

${ }^{83}$ This explanation of the relationship between rhetoric and the visual arts is found in Agricola's De Inventione Dialectica (1479); see Mack, 1992, 171, 173: "the painter who shows how an object can be depicted as swollen or concave by the way the lines are drawn, or who shows which colours return light, which shade, or how objects can be shown in a flat surface as either standing out or receding into the distance ... is teaching by means of things. These same effects can be achieved through language, so that they are not shown, but rather transmitted through words. So Plutarch spoke perceptively when he said that a poem is a speaking picture and a picture a silent poem, meaning that both teach, and what they teach is often the same: but one states what the other shows."

${ }^{84}$ Peacham, 1606, 28.

${ }^{85}$ On ekphrasis, see Ravenna; Zanker; Webb. 
and adorned with goodly tall green trees; the pleasantnesse and coolnesse of the Riuers which runne and mixe themselues in the most conuenientest places, plentifully stored with fish of seuerall natures; the variety of rare coloured Birds which flie vp and down in euery place about vs, no colour almost vnder the Sun but being reuealed in their feathers." ${ }^{86}$ The landscape is seen from the distance, and the details are represented through general nouns. However, the reference to the birds of all possible colors goes against Peacham's rules. If the birds are flying "vp and down in euery place," then the beholder is set at a varying distance from them. In this situation, a painter should remember that the farther the beholder, the weaker and more blurred colors appear. ${ }^{87}$ Instead, Drayton successfully managed to render pictorial landscapes into poetry, under the influence of the artistic principles upheld by Peacham's theories, as well as of such visual sources as landscape prints and paintings.

\section{DRAYTON'S POETIC LANDSKIP}

In Poly-Olbion Drayton developed an original descriptive ability. On several occasions, he produced pictorial landscape representations that were inspired by Dutch and Flemish theoretical and practical precepts - acquired through such manuals as Peacham's and the direct observation of works of art — and that were capable of rendering verbally the spatiality and depth of a scene. To suggest the influence of landscape depictions on some of Drayton's descriptions means to highlight not so much the ekphrastic nature of the latter's rhetorical vividness, meaning the verbal reproduction of specific works of art. Rather, it aims to stress the poet's pictorial perception and rendition of landscape, based on the selection and categorization of elements conceived in visual form, which are identified by means of the encoding of landscape features acquired through the visual arts, their perception and theory. ${ }^{88}$ In Poly-Olbion Drayton uses both rhetoric and pictorialism, as he describes Britain by means of words, that is, through verbal amplification and the accumulation of detail, and by means of things, that is, through the visualization of the subject matter thanks to universal categories within a unified framework.

The typical landscape description in Poly-Olbion can be considered halfway between a description by words and a description by things: a catalogue of natural features and their general names and characteristics, arranged within a topographical scene. For instance, in a description of Worcestershire, Staffordshire, and Warwickshire, Drayton notes:

\footnotetext{
${ }^{86}$ Raleigh, 45.

${ }^{87}$ Peacham, 1606, 30.

${ }^{88}$ Fitter, 23.
} 
So on the other side, into the Set againe,

Where Severne tow'rds the Sea from Shrewsbury doth straine,

Twixt which and Avons banks (where Arden when of old,

Her bushy curled front, she bravely did uphold,

In state and glory stood) now of three severall Shires,

The greatest portions lie, upon whose earth appeares

That mightie Forrests foot, of Worstershire a part,

Of Warwickeshire the like, which sometime was the heart

Of Arden that brave Nymph, yet woody here and there,

Oft intermixt with Heaths, whose Sand and Gravell beare,

A Turfe more harsh and hard, where Stafford doth partake,

In qualitie with those, as Nature strove to make

Them of one selfe same stuffe, and mixture, as they lye,

Which likewise in this Tract, we here together tye. ${ }^{89}$

The objects depicted by Drayton are not small details in a landscape, but the real, personified constituents of the natural landscape itself. The ambitious topographical purpose of the poem is epitomized by the use of thirty pictorial maps preceding each Song, made by William Hole (fig. 6). In Drayton's words, the maps function as an "especiall help . . . lively delineating to [the reader], every Mountaine, Forrest, River, and Valley." 90 There appears again the term lively, with strong rhetorical connotations related to a pictorial mode of description, aiming to portray what one could have observed the time on a fairly detailed map of the area. In Song 23 Drayton employs the word landskip itself in this sense, as "distant prospect, or vista," with a bird's-eye view in which Denbighshire is shown as "that Beake of land that fils, / What Landskip lies in Vales, and often rising hils." "92

In order to describe counties in the best of ways, Drayton asks his Muse the "spirit of the place" accompanying the poet and the reader around England and Wales — that she may help him correctly to portray the land:

Conduct me through these Brooks, and with a fastned clue,

Direct mee in my course, to take a perfect view

Of all the wandring Streames, in whose entransing gyres,

Wise Nature oft her selfe her workmanship admires

(So manifold they are, with such Meanders wound,

As may with wonder seeme invention to confound). ${ }^{93}$

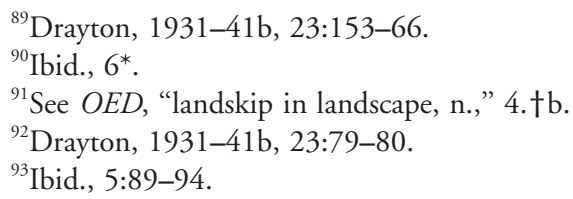




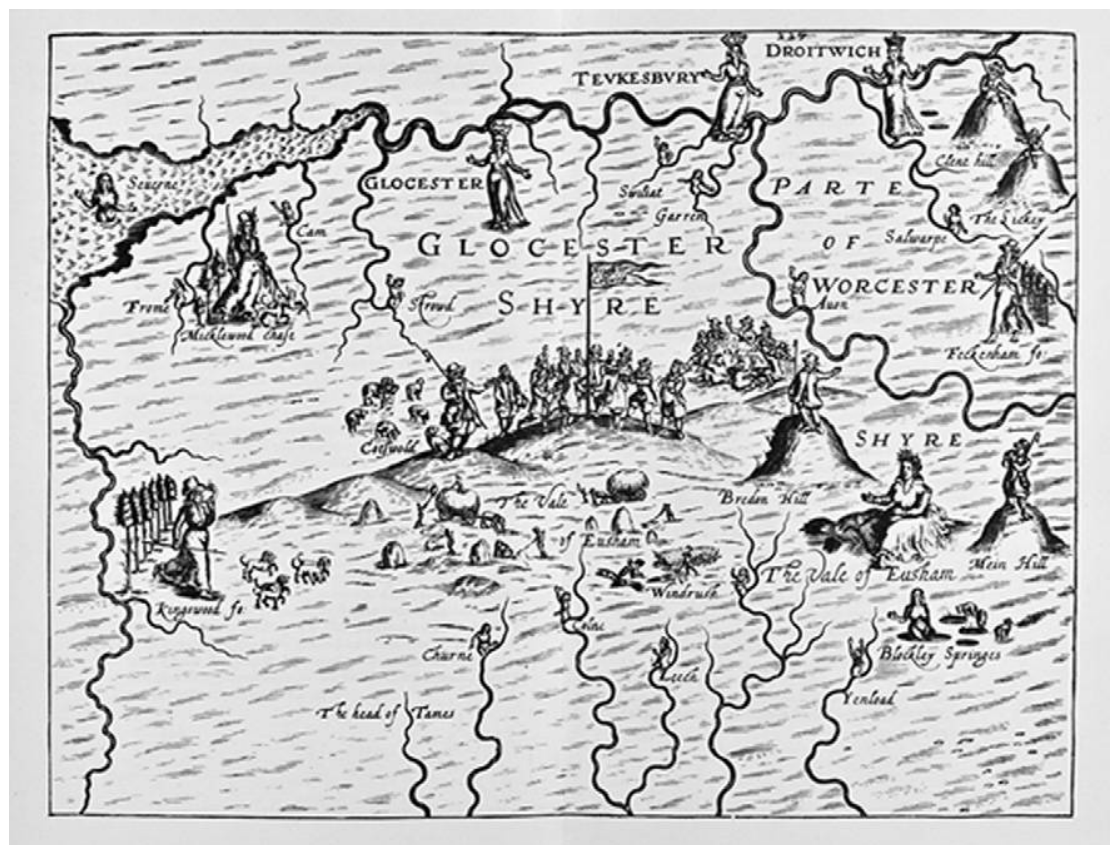

FIGURE 6. William Hole. Map XIV, in Michael Drayton, Poly-Olbion. London, 1612. Author's photograph.

This willingness to depict a "perfect view" is topographical and connected with the cartographic dimension of the poem. It is also pictorial, because it is the poet's "invention" that has carefully to reproduce by things what Nature shows visually. In Graphice, Peacham advises landscape painters not to be led astray by the infinity of invention and imitation: they should avoid errors that "overslip" their judgment in the depiction of natural landscape features, including, among others, "the natural course of riuer." "Th Topographical poetry should imitate the physical landscape through plausible and realistic descriptions, so that not only the subject matter itself be admired, but also the skill of the imitating artist. ${ }^{95}$

Nevertheless, the term landskip appears twice again in Poly-Olbion, with an important variation. This time the "cartographic gaze" is left aside in favor of a zoomed-in view representing "natural inland scenery," 96 where elements are held together by a conscious spatial arrangement

\footnotetext{
${ }^{94}$ Peacham, 1612b, 44.

${ }^{95}$ Mack, 1992, 174.

${ }^{96}$ See $O E D$, "landskip in landscape, n.," 1.
} 
determined no longer by the topographical structure of a map, but through the verbal representation of light and shadow and the rules of distance. However, Drayton had first used the word landskip in this manner in the 1603 edition of The Barons Wars, ${ }^{97}$ an instance that is worth discussing. The term appears in the description of mythological scenes painted in the chamber of Queen Isabella, at which she is looking with her lover, Mortimer: ${ }^{98}$

Upon the sundry pictures they deuise,

And from one thing they to another runne,

Now they commend that body, then those eyes,

How well that bird, how well that flower was done,

Now this part shaddowed, how that doth rise,

This top is clouded, how that trayle is spunne,

That landskip, mixtures, and delineatings,

And in that Art a thousand curious Things. ${ }^{99}$

Drayton displays a concern for spatial perspective and visual depth. ${ }^{100}$ He is uninterested in lexicographic amplification: common nouns such as "body," "eyes," "bird," and "flower" are used to refer to general categories and parts of the subject matter. Although this particular instance may be called ekphrastic in the modern sense of the word, as a poetic description of a work of art, it is also characterized by vividness, achieved through the rendering of single, general elements, through their spatial interrelationships with one another within a structured context. A comparison to the first version of this description, in the original version of the poem (published under the title Mortimeriados in 1596), particularly the last three lines, can clarify this statement: "The lively counterfetting of that sunne: / The cullors, the conceits, the shadowings, / And in that Arte a thousand sundrie things." ${ }^{101}$ In Mortimeriados it is simply said that the sun is imitated from nature, and vividly reproduced ("lively counterfetting") in painting; the colors are mentioned, as well as the artist's ingeniousness ("conceits"). But only the word "shadowings"

${ }^{97}$ Duchemin, 463-64.

${ }^{98} \mathrm{~A}$ similar scene is present in canto 33 of Ariosto's Orlando furioso (1584), and in its translation by John Harington in 1591, with Bradamante being shown around the castle and stopping to admire the paintings adorning the walls. For a brief analysis, see Hulse, $1-16$.

${ }^{99}$ Drayton, 1603, 142. "Trayle" is used as a technical term, since it referred to "a trailing ornament (carved, moulded, or embroidered) in the form of a wreath or spray of leaves or tendrils; a wreathed or foliated ornament" (OED, "trail, n.," 1, 2.a), pertaining to the terminology of the visual arts.

${ }^{100}$ Fitter, 25.

${ }^{101}$ Drayton, 1931-41a, 2518-20. 
attempts to provide a sense of space. In The Barons Wars the statement regarding the imitation of the sun becomes understood while the focus switches to the pictorial device with which the painter represents the depth deriving from light and shadow, sky light (the cloud on top of the mountain), the detailed "mixtures" of colors, and the drawing of the scene in general.

This attention to pictorial detail is specific and practical, and goes beyond the influence of literary sources per se. Drayton's description of the clouded top and light and shadow suggests at least some knowledge on his behalf of the pictorial theory and practice of landscape painting. ${ }^{102}$ The issue of light and shadow was crucial in the devising of a structural unity, where a sense of three-dimensional space, through which the gazer's eye could wander, was achieved. In landscape paintings one of the main ways of reaching this depth was the disposition of the sun and the clouds. ${ }^{103}$ As explained by Peacham in his Art of Drawing, the landscape painter should "always ... shew a fair Horizon, and expresse the heauen more or lesse eyther ouercast by clouds, or with a cleere skie, shewing the Sunne raising or setting ouer some hill or other." ${ }^{104}$ The sunrays breaking through would provide "natural" lighting effects anchoring in space the various landscape elements, and creating a sense of spatial depth. ${ }^{105}$

In the prefatory epistle to a 1610 edition of Drayton's poems, E. Hayward comments on Drayton's treatment of poetic landscapes, writing that "shadow and projection / in Lantskip [make] that which is low seeme high / That's shallow deepe, small great, and farre that's nigh." ${ }^{106}$ As theorized by Agricola, among others, this kind of poetic description equals the highlights and shadows of paintings, used to render pictorial spatiality. ${ }^{107}$ Drayton's attention to light and shadow suggests his acquaintance with sixteenth- and seventeenth-century Netherlandish landscape etchings and prints, which, far from being "linear [and] surface-bound" as Evett puts it, ${ }^{108}$ were characterized by a spatial effect determined by the contrast between a dark foreground and a lighter background. ${ }^{109}$

${ }^{102}$ I disagree with Gent, 22, who suggests that, in The Barons Wars, the 1603 revised version of Mortimeriados (1596), Drayton had "got used" to pictorial effects, and was almost ashamed of how he had been "bowled over by pictorial miracles some eight years earlier."

${ }^{103}$ Peacham, 1612b, 41.

${ }^{104}$ Peacham, 1606, 30.

${ }^{105}$ Taylor, 212, 214-15, 220, 230; Ogden and Ogden, 1955, 6.

${ }^{106}$ Drayton, 1610, $\mathrm{A} 5^{\mathrm{v}}$.

${ }^{107}$ This theory is analyzed in Mack, 1992, 171, 173. See also Gombrich, 1976, 5-18.

${ }^{108}$ Evett, 27.

${ }^{109}$ Freedberg, 27. 
Because very little is known about Drayton's life, it can only be hypothesized where he may have read about and seen landscape paintings or prints. ${ }^{110}$ From 1594 to 1597 Drayton enjoyed the patronage of Lucy Harington, Countess of Bedford (1581-1627). ${ }^{111}$ Although some years later, as one of Queen Anne's ladies-in-waiting, the countess became an important patroness and art collector, at the time when Drayton was under her protection her financial situation may not have been good enough to maintain such high standards. ${ }^{12}$ There is no evidence of any collections belonging to Sir Walter Aston (1583-1639), Drayton's patron from 1602 to 1619. Aston was, however, part of Prince Henry's circle, to which he most likely introduced Drayton. ${ }^{113}$ Peacham became a member of the prince's circle in 1607, and his few extant paintings are reminiscent of peasant scenes by Pieter Bruegel the Elder. ${ }^{114}$ There is evidence that, thanks to mutual acquaintances in the antiquarian circles of the Inns of Court, Drayton knew William Camden. ${ }^{115}$ Around the mid-1610s, Camden was in touch with a merchant and antiquary in Antwerp, who was sending him information about, and possibly helping him to purchase, Flemish "Land-schappen paintings." 116 Drayton certainly saw prints such as the Flemish-style illustrations in Spenser's Shepheardes Calender, with their crosshatching increasing shadow and depth, ${ }^{117}$ and, most likely, other successful prints such as those by Goltzius (fig. 4), and the landskips printed by Crispijn van de Passe after Jan Brueghel the Elder, around the turn of the century (fig. 7).

Returning to Poly-Olbion, Drayton's landscape depictions by things are characterized by attention to the composition of the scene, the distribution of the elements, and their role within the view. In a description of the nymph of the river Rother, flowing across the Weald, the scene shows:

${ }^{110}$ Several sixteenth- and seventeenth-century English scholars and authors are recorded as having traveled to the Netherlands, among them Ben Jonson. See Bense, 198.

${ }^{111}$ See Trevisan, 16-19.

${ }^{112}$ Archival research has suggested that before 1600 the countess's increasing household expenses and debts contracted to advance within the Elizabethan court did not allow her to foster literary patronage on a large scale. See Morgan, 48, 218; Newdigate, 66; Byard, 22-23. However, not all landscape paintings were very expensive, and she may still have been able to afford some.

${ }^{113}$ In 1610, Drayton began to receive an annuity of ten pounds from Prince Henry. See Newdigate, 197.

${ }^{114}$ Horden; Hayes, 40, 45n10.

${ }^{115}$ Newdigate, 93.

${ }^{116}$ Harding, 65-66.

${ }^{117}$ Luborsky, 10. 


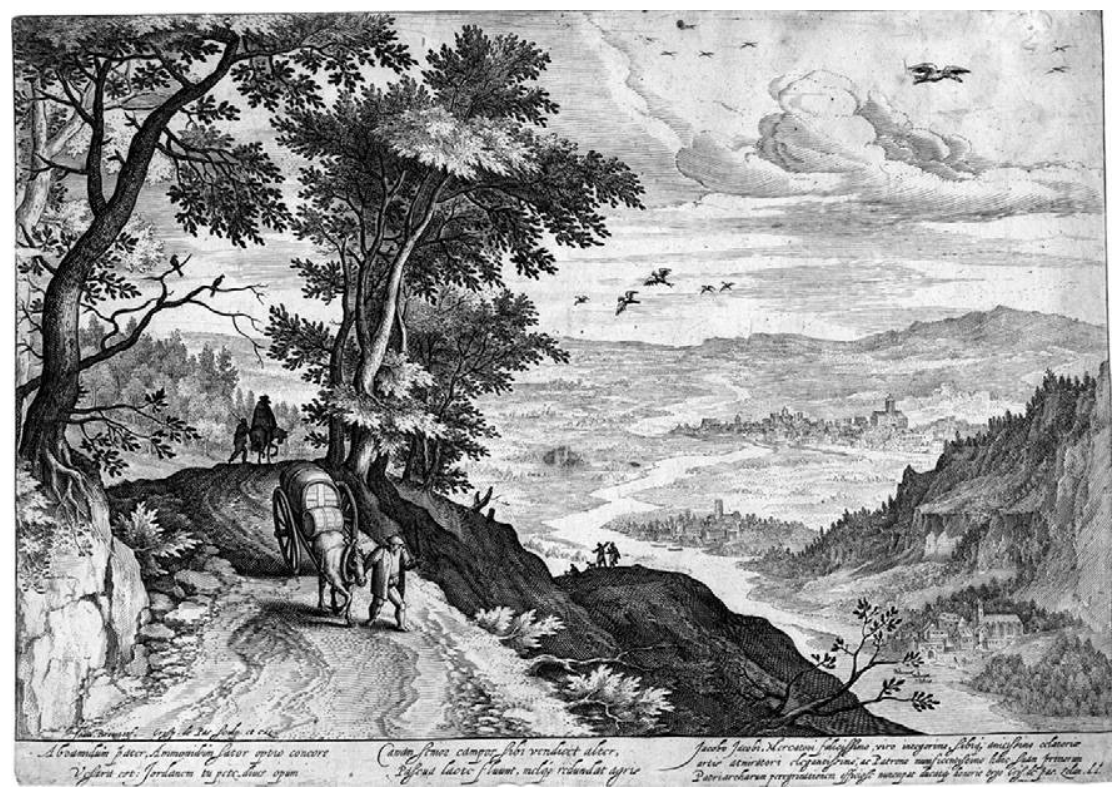

FIGURE 7. Crispijn van de Passe (printed by). after Jan Bruegel the Elder. Landscape, ca. 1600. London, (C) The Trustees of the British Museum.

well-spread Horse, large Sheepe, and full-fed Neate.

Some wallowing in the grasse, there lie a while to batten;

Some sent away to kill; some thither brought to fatten;

With Villages amongst, oft powthred heere and there;

And (that the same more like to *Landskip should appeare)

With Lakes and lesser Foards, to mitigate the heate. ${ }^{118}$

The star marking the word landskip points to the page margin, where Drayton defined it as "the naturall expressing of the surface of a Country in Painting." Around 1611-12, when Drayton was completing part 1 of Poly-Olbion, landskip was still a rather uncommon term, referring to what was equally a rather uncommon subject for paintings. Drayton echoes, from a lexical point of view, Peacham's definition in The Art of Drawing, where landskip is described as the "expressing of the land by hills, woodes, Castles, seas, valleys, ruines, hanging rocks, Citties, Townes, etc., as farre as may bee shewed within our Horizon."

${ }^{118}$ Drayton, 1931-41b, 18:32-37.

${ }^{119}$ Peacham, 1606, 28-31. Levy, 181; Semler, 2004, 743, 750. It seems unlikely that Drayton had the chance to see Peacham's Graphice, the enlarged edition of The Art of Drawing, as it was published only three months before the first part of Poly-Olbion was entered in the Stationers' Register. 
The spatial view defined by place adverbs such as "there" and "heere and there," 120 and the use of common words as parts of the compositional subject matter, suggest that this passage is an instance of the spatial rendering influenced by the theory of landscape painting. ${ }^{121}$ General common nouns are used, according to the visual-rhetorical theory proposed by Peacham in his section on landscape drawing. The farther away an object, Peacham says, the more difficult it is to tell its main features, because particulars are blurred and annihilated by the distance: so, the farther from the observer a landscape feature is, the better defined it is by its universal category, rather than one of its types. ${ }^{122}$

The scene is reminiscent of what David Freedberg calls the "evocative realism" of Dutch landscape prints. ${ }^{123}$ The single parts of the poetic landscape are arranged in order to provide a three-dimensional view so that the reader can explore the portrayed scene visually. The foreground and middle ground are occupied by horses, sheep, and cows, engaged in the cyclical phases of cattle life. The uses of "some" to describe the activities connected with cattle imply a spatial distribution and related human activities that are imagined but not shown. Movement is reduced to a minimum, and even the busy villages in the background are presented as self-contained active spots whose life is inferred, but not shown in detail. ${ }^{124}$ The "lesser" rivers - which could refer either to their actual size or to their size within the view - provide a sense of distance. This scene has depth, and presents a landscape that feels as if it were "accessible with one's feet." Right from the introduction "to the Generall Reader," Drayton highlights this peripatetic rationale, when he writes that "through most delightfull Groves the Angellique harmony of Birds shall steale thee to the top of an easie hill ... then ... . downe by a soule-pleasing Descent through delicate embrodered Meadowes, often veined with gentle gliding Brooks . . . which shall lead thee, to most pleasant Downes, where harmlesse Shepheards are." 125

It is worthwhile recalling the identical three-dimensional way in which the nineteenth-century critic A. H. Bullen described his reaction to the reading of Poly-Olbion: "a saunter down a Surrey lane when the nuts are ripening is the one thing pleasanter than a ramble through the Poly-Olbion....

${ }^{120}$ Foster, 395-96.

${ }^{121}$ Peacham, 1606, 29-31.

${ }^{122}$ Ibid., 30.

${ }^{123}$ Freedberg, 13.

${ }^{124}$ According to Hagstrum, 22, in a pictorial description, the depiction of a visual object in verbal form implies the "reduction of motion to stasis," and the remaining motion "must be viewed against the basic motionlessness of the arrangement."

${ }^{125}$ Drayton, 1931-41b, 5*. 
The Polyolbion carries the reader through hundreds of pages in the swing and sweep of the bounding verse.... The long rolling verse has something of the springiness of heather; we cover the ground insensibly, and find a growing delight in the labour." ${ }^{126}$ Drayton was experimenting with a new pictorial vividness, which, as in those pictures where an excellent compositional effect is achieved, would make his readers feel as if they could take a walk in the landscape described. This idea was propounded by Dutch art theorists, and was the basis of the spatial organization of landscape paintings: the beholder was invited to take a wandeling, to take a walk in the countryside, presented as a familiar landscape. ${ }^{127}$

Song 26, which appeared in 1622 , presents a scene that is very similar to that in The Barons Wars. It describes the nymph of the river Soar, in the East Midlands, whose slow flow suggests the comparison to "some young tender Mayd, / Entring some Princes Court, which is for pompe arayd." She is led from room to room, and lingers in amazement while observing the beds, the blankets, and the "Large Galleries, where piece with piece doth seeme to strive, / Of Pictures done to life, Landskip, and Perspective." ${ }^{128}$ James Turner suggests that "Landskip, and Perspective" is a hendiadys meaning simply "pictures in general," without any specific regard for their subject. ${ }^{129}$ But in this context the hypothesis that landskip should refer to the very subject of the paintings, and that a personified river should admire landscape paintings on the sides of her course, makes poetic sense. "Perspective" most likely refers to the surrounding prospects of the land. The technical phrase "done to life," like its Dutch counterpart, naer het leven, suggests that "the elements of the work [of art] have been taken from life," and are plausible, realistic, and often topographically accurate, ${ }^{130}$ as the nymph of the river Soar is actually looking at real landscapes adorning her own banks.

Drayton was clearly interested in the concept of images done to life. Like its Dutch counterpart, this phrase states in a nutshell that the image in a drawing or painted work is based on an actual model, and is not filtered by the artist's fancy. ${ }^{131}$ In his Art of Drawing, Peacham uses the phrase "drawe by the life" as related to a portrait, meaning "to draw by the living model" as opposed to imagining it. ${ }^{132}$ Furthermore, as has already been mentioned, in

${ }^{126}$ Bullen, 20.

${ }^{127}$ Gibson, 119; Freedberg, 15. The phrase "accessible with one's feet" is taken from Goeree, 62: quoted in Taylor, 212-13.

${ }^{128}$ Drayton, 1931-41b, 26:81-88.

${ }^{129}$ Turner, 292.

${ }^{130}$ Freedberg, 11.

${ }^{131}$ Swan, 354-56.

${ }^{132}$ Peacham, 1606, 20; OED, “life, n.," P5.a-b. 
his Mortimeriados Drayton describes some paintings as showing the "lively counterfetting" of the sun, ${ }^{133}$ meaning that the sun is imitated from nature and vividly reproduced in painting. The term counterfeit belongs to technical vocabulary connected with pictorial depictions done to life, with its Dutch counterpart - gheconterfeyt naer het leven - being used in relation to landskips as well. Indeed, in the sixteenth and seventeenth centuries artistic images conceived and defined as counterfeits (contrafacta) were especially considered "bearers of visual fact"; ${ }^{134}$ and, like them, those said to have been conceived and made naer het leven implied "a verifiable conformity with their subject, an iconic correspondence." 135 Again, Peacham uses the same term in a similar way, when, by comparing sculpture to painting, he concludes that "painting is tied to counterfeite all shadowes, expresse the life, sence and passion, whereas in carving they fall in with the chissel": ${ }^{136}$ unlike sculpture, which naturally partakes of the effects of real light and shadow and physical sensuousness, painting has to vividly imitate and reproduce shadows and sensations from life.

It is rather telling that Drayton did not think he had to define the word landskip when he was describing the procession of the nymph of the river Soar in 1622. In the meantime, the pictorial subject of landskips had made a gradual breakthrough in England, and had come to be slowly regarded as a genre in its own right. ${ }^{137}$ This change surfaces also in the 1612 reprint of Peacham's manual. The section on landscape is expanded and the subject is presented in a more complex manner ${ }^{138}$ when Peacham stresses, though still cautiously, that a "full view of incidental subject matter," in the sense of non-natural elements, is most pleasing, "because it feedeth the eie with varietie." 139 Drayton too wanted to depict "the varying earth" through words guided by his "varying vaine," ${ }^{140}$ and, after presenting a landscape with domestic animals and pastures, he decided to focus his "incidental subject matter" around human everyday life.

${ }^{133}$ Drayton, 1931-41a, 2518.

${ }^{134}$ Parshall, 555.

${ }^{135}$ Swan, 356.

${ }^{136}$ Peacham, 1606, 8.

${ }^{137}$ In the mid-1620s, in his Art of Limning, Edward Norgate still considered landscape painting as an "art soe new in england, and soe lately come ashore": quoted in Hayes, 40.

${ }^{138}$ Peacham's Graphice, printed in 1612, could have influenced only the second part of Poly-Olbion, since the former was entered in the Stationers' Register on 16 December 1611, only three months before the first part of Poly-Olbion was published.

${ }^{139}$ Similarly, van Mander thought that variety was a "source of beauty": quoted in Becker, 285.

${ }^{140}$ Drayton, 1931-41b, 2:8. 
The last example from Poly-Olbion concerns the depiction of a scene in the Fens:

The toyling Fisher here is tewing of his Net:

The Fowler is imployd his lymed twigs to set.

One underneath his Horse, to get a shoot doth stalke;

Another over Dykes upon his Stilts doth walke:

There other with their Spades, the Peats are squaring out,

And others from their Carres, are busily about,

To draw out Sedge and Reed, for Thatch and Stover fit,

That whosoever would a Landskip rightly hit,

Beholding but my Fennes, shall with more shapes be stor'd,

Then Germany, or France, or Thuscan can afford. ${ }^{141}$

Drayton re-creates a landskip with perspectival markers (place adverbs) and a pictorial composition with a high horizon. ${ }^{142}$ His reference to landscape painting is confirmed by his inclusion of examples of views that Peacham defines as the "fairest and most beautifull Landtskips in the world": Italy, France, and Germany, but also Windsor and London. ${ }^{143}$ Drayton's appreciation of the land in Poly-Olbion resembles the general feeling pervading Dutch and Flemish landskips around the 1610s.

The depictions of workers undertaking some kind of action add to the narrativity of a painting, ${ }^{144}$ but also, as noted by W. S. Gibson, they "enhance the sense of space in the landscape . . . by suggesting distances already covered or yet to be travelled." 145 Such depiction of everyday activities populating Dutch and Flemish landskips are reproduced in the Poly-Olbion maps, ${ }^{146}$ and are also implicitly present in the villages in the abovementioned passage (18:32-37). According to Peacham, in an invented scene within a verisimilar landscape, the painter shall "please very well" by showing, beside cities, mansions, havens, and forests, also "a countrey village, faire or market ... peasants together by the eare, and the like."147 Peacham, however, warns the artist to use his judgement, so as to prevent his work becoming "ridiculous to the beholders eye" for not having correctly observed the rules of distance and "accident." By this he also means

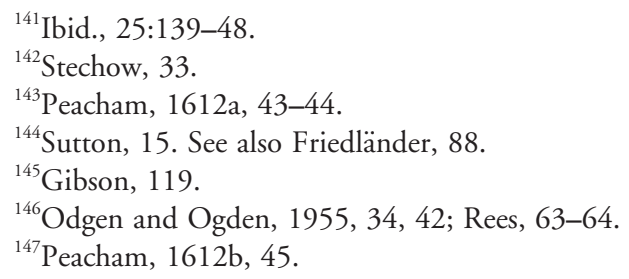


following the specific attributes of the season in which the landscape is set: "Not as the foolish Painter [who] . . . beginning with Ianuary, drew him sitting in a wicker chair like an old man, with three or four night caps on his head by the fire . . \& \& without doors haycocks, greene trees, and as if it had beene in the midst of Iuly. Wherefore I say such a winter peece should be graced and beautified with all manner of workes and exercises of winter, as foot ball, felling of wood, sliding vpon the yce, batfowling by night, hunting the beares, or foxe in the snow, making you trees euery where bare or laden with snow, the earth without flowers, and catell, the ayre thicke with clouds, riuers and lakes frozen, which you may shew by cartes passing ouer, or boyes playing vpon the same, and a thousand the like."148

The painter should follow the old tradition of calendrical depictions, celebrated so often in Dutch and Flemish prints, which assigns specific occupations to each part of the year. Peacham must have had in mind instances showing such activities with a landscape in the background: for example, the representation of the seasons after Pieter Bruegel the Elder (fig. 8) and those after Hans Bol, printed by Pieter van der Heyden in the 1570s and reprinted with great success around 1600 (figs. 9-10). Seasonal activities were easy to describe, but monthly activities were not so strictly set. For instance, Peacham assigns tree-chopping to the month of January, whereas it was also often used for September or February. ${ }^{149}$

Despite these loose boundaries, Drayton's landscapes in the two main passages seen before are incorrect from this point of view. Lines 18:32-37 describe cattle and villages spread over a country scene, with horses, cows, and sheep in the foreground and a long prospect in the background, reminiscent of Bol's print of Adam and Eve (fig. 3). Although the lake and rivers in the landscape are supposed to "mitigate the heate," the reasons for the cattle's presence do not fit. ${ }^{150}$ If in the summertime cows and sheep are seen "wallowing in the grasse ... to batten," they are not "brought to fatten" or "sent to kill." The last two are calendrical activities associated with the months of November and December, when swine, in particular, are fed acorns so that they may get fatter before being killed to produce meat for the winter. ${ }^{151}$

${ }^{148}$ Ibid., 44-45.

${ }^{149}$ Pearsall and Salter, 130; Luborsky, 21.

${ }^{150}$ Another motif often connected with summertime, especially with the month of June, is sheep-shearing: Luborsky, 21. See also Abel Grimmer (1570-1619), The Month of June: A Landscape with Christ the Good Shepherd, and Hans Bol, Landscape with Shepherds and Flocks.

${ }^{151}$ Pearsall and Salter, 130. An example of this is found, for instance, in a print by the Antwerp artist Abel Grimmer, produced in 1607 and depicting the month of December, with the slaughtering of animals. 


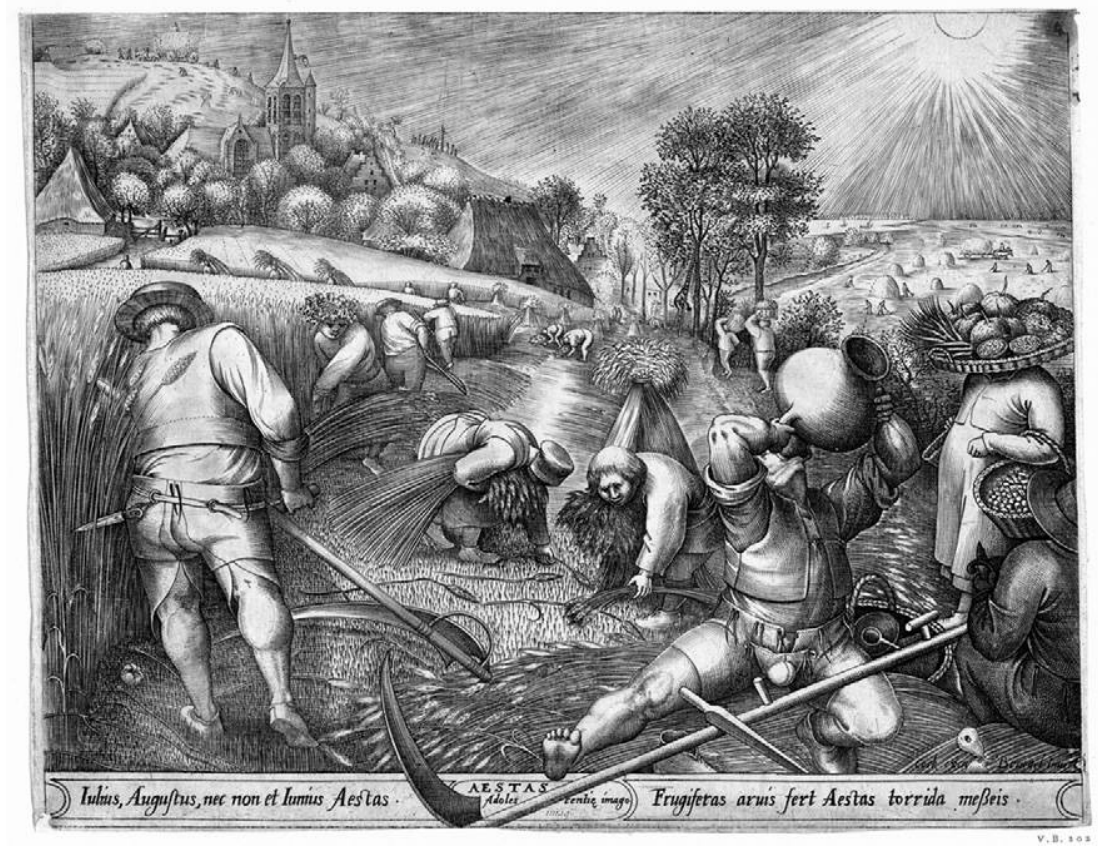

FIGURE 8. Pieter van der Heyden (printed by), after Pieter Bruegel the Elder. Aestas, 1570. London, (C) The Trustees of the British Museum.

Lines 25:139-48 show a landscape in which human country activities typical of Dutch and Flemish paintings and prints overlap without any concern for the seasons, but almost all of them are tied to the specific environment in which they occur: the Fens. The fisher and his net, a widespread motif in prints, and the fowler behind his stalking-horse, ${ }^{152}$ are typical of late spring and summer months. But the gathering of reeds for house thatching is a late autumn and early winter activity. ${ }^{153}$ The harvest of sedge does not occur at the same time as that of reeds: sedge is cut in the summer, and this will prevent any reed growth for that year. The "squaring out of Peats" for fuel, typical of marshy areas, belongs to the late autumn months, while walking on a dike on stilts would be nearly impossible when the water is frozen. The scene of the fowler setting his "lymed

${ }^{152}$ OED ("stalking horse, n.," 1): "A horse trained to allow a fowler to conceal himself behind it or under its coverings in order to get within easy range of the game without alarming it. Hence, a portable screen of canvas or other light material, made in the figure of a horse (or sometimes of other animals), similarly used for concealment in pursuing game."

${ }^{153}$ See de Ramaix, 70:4.0.21. 


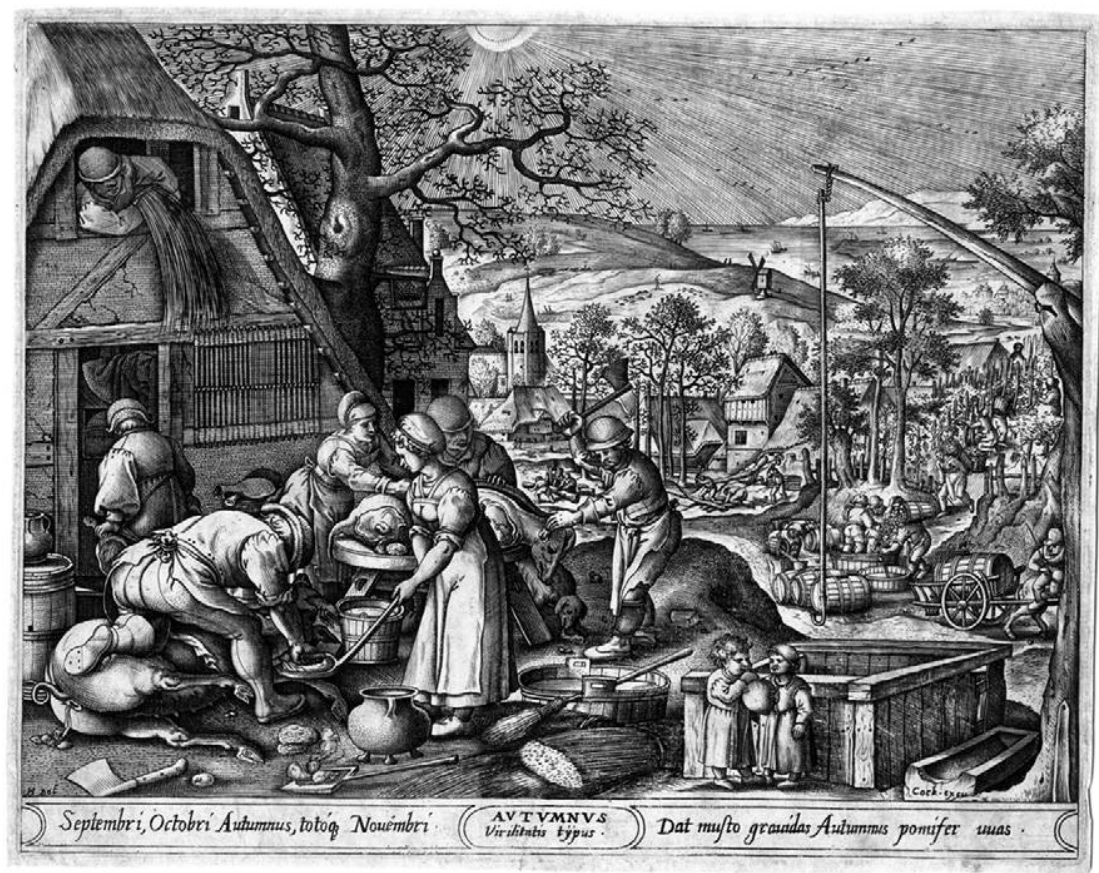

FIGURE 9. Pieter van der Heyden (printed by), after Hans Bol. Autumns, ca. 1570. London, (C) The Trustees of the British Museum.

twigs" to catch birds is peculiar: it was a way of hunting fowls that became known in England in the late sixteenth century. It was often depicted in prints by Dürer and Stradanus (around 1600), among others, but never in illustrations of England and the English countryside. ${ }^{154}$ Drayton's use of this imagery around the late 1610 s reflects a quite recent familiarity with the activity, proved by other contemporary English works, but also by some direct experience of its representation through foreign prints. ${ }^{155}$ The marshy environment in general is reminiscent of Netherlandish scenes, and the area described by Drayton, located in Lincolnshire, was incidentally known as the county of Holland.

What is most interesting in these descriptions is Drayton's localizing intent. His landscapes are imaginary narrative scenes within a recognizable

${ }^{154}$ Stumpel, 148-49.

${ }^{155}$ See, for instance, Burton, 1621, 2:2.4.341: "Fowling is . . . delightsome to some sorts of men, be it with guns, lime, nets, gins, strings, pitfals, pipes, calls, stawking-horses, setting dogges, \& c." 


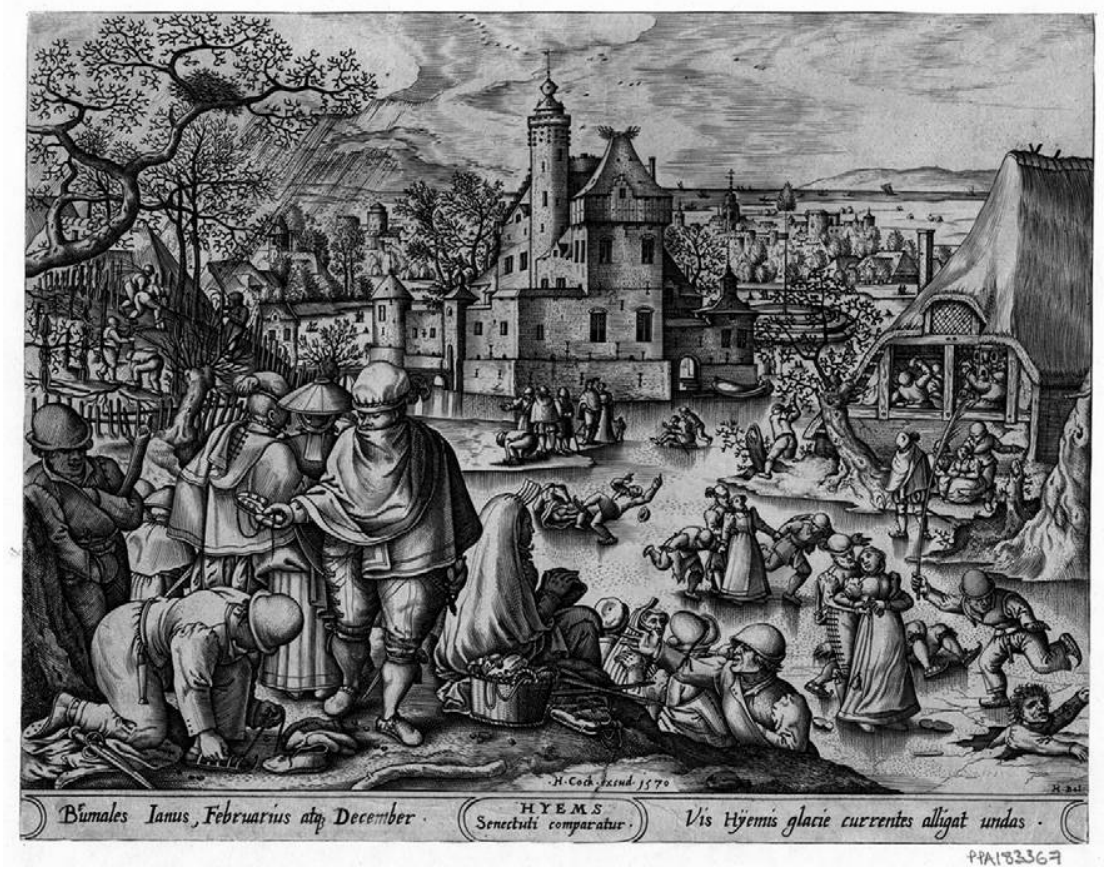

FIGURE 10. Pieter van der Heyden (printed by), after Hans Bol. Hyems, 1570. London, (C) The Trustees of the British Museum.

topographical area: they are "taken from life." ${ }^{156}$ The temporary lack of verisimilitude created by the different, overlapping seasonal occupations is dictated by Drayton's ultimate poetic intention to give a pictorial depiction of all possible local activities, summarizing the identity of a specific area.

\section{CONCLUSION}

This article has highlighted how important the influence of Dutch and Flemish landscape-painting theory and practice was for Drayton's pictorial experimentations in the poetic depiction of the land of Britain. It has also shown ways in which poetic descriptions can reflect a particular school of painting through an analysis of specific techniques used to integrate visual perception, rhetoric, and art vocabulary.

Beside improving the general, critical knowledge on the relationship between poetry and painting, a literary analysis of Drayton's descriptive

\footnotetext{
${ }^{156}$ Rubinstein, 170 .
} 


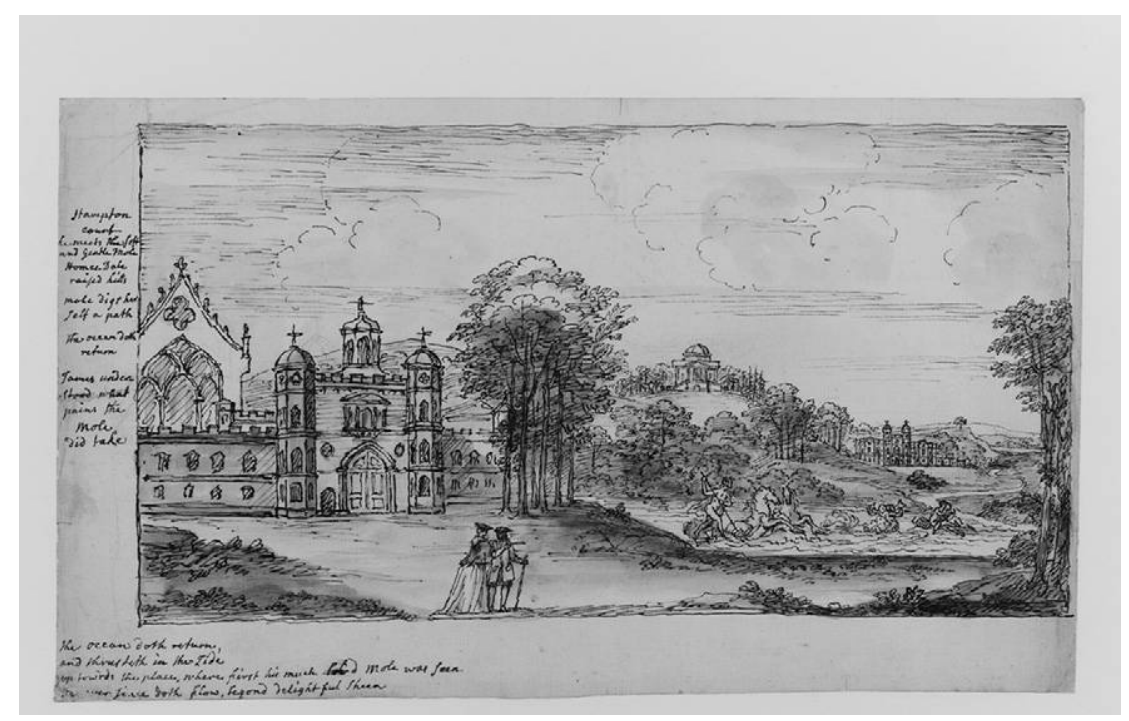

FIGURE 11. William Kent. Landscape Capriccio with Hampton Court, Esher, and River Scene with Triton (Illustration to Michael Drayton's Poly-Olbion). London, (C) The Trustees of the British Museum.

technique sheds a light onto a different, aesthetic interpretation of landscape. Through its pictorial, geographical localization of such longstanding literary genres as river and pastoral poetry, Drayton's Poly-Olbion marked a turning point in poetic landscape descriptions: it contributed to the canonization of a British set of landscape views that would become an essential part of the literary tradition, and that would inspire topographical descriptions of Britain and aesthetic reflections on its national landscape up to the twentieth century. ${ }^{157}$ The most striking, and perhaps flattering, tribute to Drayton's landscape pictorialism was made over a hundred years after the composition of Poly-Olbion. It is a drawing in the picturesque style of the stretch of the Thames by Hampton Court palace, designed by an artist with a similar kind of sensitivity — the landscape architect William Kent (1685-1748) (fig. 11) $)^{158}$ - a visual work of art inspired by pictorial poetry.

\section{BRUNEL UNIVERSITY, LONDON}

${ }^{157}$ See Trevisan, 261-94.

${ }^{158}$ Kent's engraving is entitled Landscape Capriccio with Hampton Court, Esher, and River Scene with Triton (ca. 1720-39), and is discussed in Hunt, 56-58. For a full analysis of Poly-Olbion's influence on English literature from the seventeenth to the twentieth centuries, see Trevisan, 261-94, esp. 281-84. 


\section{Bibliography}

Adrian, John M. Local Negotiations of English Nationhood, 1570-1680. New York, 2011.

Becker, Jochen. "The Pleasures of Variety: Remarks on Landscape." In Théories des artes et creation artistique dans l'Europe du Nord du XVI au début $d u X V I I I^{e}$ siècle, ed. Michèle-Caroline Heck, Frédérique Lemerle, and Yves Pauwels, 273-90. Villeneuve d'Ascq, 2002.

Bender, John B. Spenser and Literary Pictorialism. Princeton, 1972.

Bense, Johan F. Anglo-Dutch Relations. London, 1925.

Bullen, Arthur H. Selections from the Poems of Michael Drayton. Chilsworth, 1883.

Burton, Robert. Anatomy of Melancholy. 2 vols. London, 1621.

-. Anatomy of Melancholy. 2 vols. London, 1624.

Byard, Margaret M. "The Trade of Courtiership: The Countess of Bedford and the Bedford Memorials; A Family History from 1585 to 1607 ." History Today 29 (1979): 20-28.

$\rightarrow$ Cosgrove, Denis. "Prospect, Perspective and the Evolution of the Landscape Idea." Transactions of the Institute of British Geographers 10 (1985): 45-62.

Daye, Angel. The English Secretorie. London, 1586.

Dekker, Thomas. The Seven Deadly Sins. London, 1606.

Delano-Smith, Catherine, and Roger J. P. Kain. English Maps: A History. London, 1999.

Drayton, Michael. The Barrons Wars. London, 1603.

- Poems by Michael Drayton, Esq. London, 1610.

- Mortimeriados. In The Works of Michael Drayton (1931-41a), 1: 305-92.
- Poly-Olbion. In The Works of Michael Drayton (1931-41b), vol. 4.

Duchemin, H. P. "Michael Drayton's PolyOlbion: A Critical and Historical Study." PhD diss., Birkbeck College, University of London, 1975.

Dunthorne, Hugh. "Eighteenth-Century English Perceptions of the Landscape and Landscape Painting of the Netherlands." Dutch Crossing 31.1 (1987): 41-53.

Dutch and Flemish Artists in Britain 1550-1800, Leids Kunsthistorisch Jaarboek. Ed. Juliette Roding and Eric Jan Sluijter. Leiden, 2003.

Evett, David. Literature and the Visual Arts in Tudor England. Athens, GA, 1990.

Ewell, Barbara C. "Michael Drayton: England's Body Immortalized." Studies in Philology 75 (1978): 297-315.

Farmer, Norman K. Poets and the Visual Arts in Renaissance England. Athens, GA, 1990.

Fitter, Chris. Poetry, Space, Landscape: Toward a New Theory. Cambridge, 1995.

Foster, John W. "A Redefinition of Topographical Poetry." Journal of English and German Philology 69.3 (1970): 394-406.

Freedberg, David. Dutch Landscape Prints of the Seventeenth Century. London, 1980.

Friedland, Louis S. "The Illustrations in the Theatre for Worldlings." Huntington Library Quarterly 19.2 (1956): 107-20.

Friedländer, Max W. Landscape - Portrait Still Life. Trans. R. F. C. Hull. Oxford, 1949.

Gelder van, J. G. "Notes on the Royal Collection: IV. The 'Dutch Gift' of 1610, to Henry, Prince of 'Whalis,' and Some Other Presents." Burlington Magazine 105.729 (1963): 541-45.

Gent, Lucy. Picture and Poetry: Relationships between Literature and the Visual Arts in 
the English Renaissance. Leamington Spa, 1981.

Gerard, Robert A. "Woutneel, de Passe and the Anglo-Netherlandish Print Trade." Print Quarterly 13 (1996): 363-76.

Gibson, Walter S. Pleasant Places: The Rustic Landscape from Bruegel to Ruisdael. Berkeley, 2000.

Goeree, Willem. Inleyding tot de Praktyk der Algemeene Schilderkonst. Middleburg, 1668.

Gombrich, Ernst H. "Renaissance Artistic Theory and the Development of Landscape Painting." In Norm and Form: Studies in the Art of the Renaissance, 5-18. London, 1966.

- The Heritage of Apelles. Ithaca, 1976.

Gottfried, Rudolf B. "Spenser and the Italian Myth of Locality." Studies in Philology 34 (1937): 107-25.

Grant, Maurice H. A Chronological History of Old English Landscape Painters. 7 vols. Leigh-on-Sea, 1957.

Griffiths, Anthony. The Print in Stuart Britain 1603-1689. London, 1998.

Hadfield, Andrew. "Spenser, Drayton and the Question of Britain." Review of English Studies 51 (2000): 582-99.

Hagstrum, Jean H. The Sister Arts: The Tradition of Literary Pictorialism and English Poetry from Dryden to Gray. Chicago, 1958.

Harding, Robert J. D. "Was William Camden a Collector of Flemish Landscapes?" British Art Journal (2009): 65-66.

Hayes, John. "British Patrons and Landscape Painting.” Apollo 18 (1965): 38-46.

Hearn, Karen, ed. Dynasties: Painting in Tudor and Jacobean England. London, 1995.

. "A Question of Judgment: Lucy Harington, Countess of Bedford, as Art Patron and Collector." In The Evolution of English Collecting, ed. Edward Chaney, 221-39. London, 2004.
Helgerson, Richard. Forms of Nationhood: The Elizabethan Writing of England. Chicago, 1992.

Hind, Arthur M. Engraving in England in the Sixteenth and Seventeenth Centuries. 3 vols. Cambridge, 1952-64.

Horden, John. "Peacham Henry (b. 1578, d. in or after 1644)." In Oxford Dictionary of National Biography. Oxford, 2004. doi: 10.1093/ref:odnb/ 21667.

Howell, Wilbur S. Logic and Rhetoric in England 1500-1700. New York, 1961.

Hulse, Clark. The Rule of Art: Literature and Painting in the Renaissance. Chicago, 1990.

Hunt, John Dixon. William Kent: Landscape Garden Designer. London, 1987.

Klein, Bernhard. "Imaginary Journeys: Spenser, Drayton, and the Poetics of National Space." In Literature, Mapping and the Politics of Space in Early Modern Britain, ed. A. Gordon and B. Klein, 204-23. Cambridge, 2001a.

- Maps and the Writing of Space in Early Modern England and Ireland. New York, 2001b.

Lagerlöf, Margaretha L. Ideal Landscape: Annibale Carracci, Nicolas Poussin, and Claude Lorrain. New Haven, 1990.

Lee, Rensselaer W. "Ut Pictura Poesis: The Humanistic Theory of Painting." Art Bulletin 22.4 (1940): 197-269.

Levesque, Catherine. Journey Through Landscapes in Seventeenth-Century Holland. University Park, PA, 1994.

Levy, F. J. "Henry Peacham and the Art of Drawing." Journal of the Warburg and Courtauld Institutes 37 (1974): 174-90.

Luborsky, Ruth S. "The Illustrations of the Shepheardes Calender." Spenser Studies 2 (1981): 3-53.

Lunde, Ingunn. "Rhetorical Enargeia and Linguistic Pragmatics." Journal of Historical Pragmatics 5.1 (2004): 49-80. 
Maartens, Maximiliaan, and Natasja Peeters. “'A Tale of Two Cities': Antwerp Artists and Artisans in London in the Sixteenth Century." In Dutch and Flemish Artists in Britain 1550-1800 (2003), 31-42.

Mack, Peter. "Agricola's Use of the Comparison Between Writing and the Visual Arts." Journal of the Warburg and Courtauld Institutes 55 (1992): 169-79.

$\rightarrow-$ Elizabethan Rhetoric: Theory and Practice. Cambridge, 2002.

McEachern, Claire. The Poetics of Nationhood, 1590-1612. Cambridge, 1996.

Millar, Oliver, ed. "Catalogue of the Collections of Charles I, by Abraham van der Doort." Walpole Society 37 (1958-60): 1-256.

Morgan, Florence H. "A Biography of Lucy, Countess of Bedford." PhD diss., University of Southern California, 1956.

Newdigate, Bernard H. Michael Drayton and His Circle. Oxford, 1961.

$\rightarrow$ Ogden, Henry V. S., and Margaret S. Ogden. "A Bibliography of SeventeenthCentury Writings on the Pictorial Arts in English." Art Bulletin 29.3 (1947): 196-207.

- English Taste in Landscape in the Seventeenth Century. Ann Arbor, 1955.

Parshall, Peter W. "Imago Contrafacta: Images and Facts in the Northern Renaissance." Art History 16 (1993): 554-79.

Peacham, Henry. The Garden of Eloquence. London, 1577.

The Art of Drawing with the Pen. London, 1606.

- The Gentleman's Exercise. London, 1612a.

- Graphice. London, 1612b.

. The Compleat Gentleman. London, 1634.

Pearsall, Derek, and Elizabeth Salter. Landscapes and Seasons of the Medieval World. London, 1973.

Praz, Mario. Mnemosyne: The Parallel Between Literature and the Visual Arts. Princeton, 1974.
Prosperetti, Leopoldine Van Hogendorp. Landscape and Philosophy in the Art of Jan Brueghel the Elder (1568-1625). Farnham, 2009.

Raleigh, Walter. The True Description of Guiana. London, 1617.

de Ramaix, Isabelle. "Johan Sadeler I." In The Illustrated Bartsch, 70:1-2. New York, 1999.

Ravenna, Giovanni. "Per l'identità di ekphrasis." Incontri triestini di filologia classica 4 (2004-05): 21-30.

Rees, Ronald. "Historical Links Between Cartography and Art." Geographical Review 70.1 (1980): 60-78.

Revard, Stella P. "The Design of Nature in Michael Drayton's Poly-Olbion.” Studies in English Literature, 1500-1900 17 (1977): 105-17.

Rubinstein, Greg M. G. "Artists from the Netherlands in Seventeenth-Century Britain: An Overview of their Landscape Work." In The Exchange of Ideas: Religion, Scholarship and Art in AngloDutch Relations in the Seventeenth Century, ed. Simon Groenveld and Michael J. Whintle, 163-91. Zutphen, 1994.

Semler, Liam E. The English Mannerist Poets and the Visual Arts. Madison, 1998.

_. "Breaking the Ice of Invention: Henry Peacham's The Art of Drawing (1606)." Sixteenth Century Journal 35.3 (2004): 735-50.

Seznec, Jean. "Art and Literature: A Plea for Humility." New Literary History 3.3 (1972): 569-74.

Silver, Larry. Peasant Scenes and Landscapes: The Rise of Pictorial Genres in the Antwerp Market. Philadelphia, 2006.

Sluijter, Eric Jan. “The English Venture: Dutch and Flemish Artists in Britain, 1550-1800." In Dutch and Flemish Artists in Britain 1550-1800 (2003), 11-30.

Stechow, Wolfgang. Dutch Landscape Painting of the Seventeenth Century. London, 1966. 
Strong, Roy. The English Icon: Elizabethan and Jacobean Portraiture. London, 1969.

Stumpel, Jeroen. "The Foul Fowler Found Out: On a Key Motif in Dürer's 'Four Witches.” Simiolus 30.3-4 (2003): 143-60.

Sutton, Peter C., ed. Masters of $17^{\text {th }}$ Century Dutch Landscape Painting. London, 1987.

Swan, Claudia. "Ad vivum, near het leven, from the life: Defining a Mode of Presentation." Word and Image 11.4 (1995): 353-72.

Sypher, Wylie. Four Stages of Renaissance Style: Transformations in Art and Literature, 1400-1700. Garden City, NY, 1955.

Taylor, Paul. "The Concept of Houding in Dutch Art Theory." Journal of the Warburg and Courtauld Institutes 55 (1992): 201-32.

Trevisan, Sara. "Michael Drayton's PolyOlbion: A Study in Perspective." PhD diss., University of Padua, 2010.

$\rightarrow$ Turner, James. "Landscape and the "Art Prospective,' 1584-1660." Journal of the Warburg and Courtauld Institutes 42 (1979): 290-93.

Veldman, Ilja M. Images for the Eye and Soul: Function and Meaning in Netherlandish Prints 1450-1650. Leiden, 2006.

Veltman, Kim. "Military Surveying and Topography: The Practical Dimension of Renaissance Linear Perspective." Revista de Universidade de Coimbra 17 (1979): 269-79.

Vertue, George. "II. Note-books A.g and A.c (Add. MSS. 23070; 23075)." Walpole Society 20 (1931-32). -. "V. Note-books A.y.y., A.w., B.3 and D.1 (Add. MSS. 23073; 22042;
23087; 23089)." Walpole Society 26 (1937-38).

Walpole, Horace. Anecdotes of Painting in England. 3 vols. London, 1849.

Waterhouse, Ellis K. English Painting 1530-1790. London, 1953.

Webb, Ruth. "Ekphrasis Ancient and Modern: The Invention of a Genre." Word \& Image 15.1 (1999): 7-18.

Weisstein, Ulrich. "Comparing Literature and Art: Current Trends in Critical Theory and Methodology." In Literature and the Other Arts, ed. Zoran Konstantinovic, Steven P. Scher, and Ulrich Weisstein, 19-30. Innsbruck, 1981.

Wellek, René. "Parallelism Between Literature and the Arts." English Institute Annual, 1941, 95-128. New York, 1942.

Wells-Cole, Anthony. "The Patronage of Elizabeth Countess of Shrewsbury and Hardwick: A Study in the Influence of Netherlandish Prints in SixteenthCentury England." In Dutch and Flemish Artists in Britain 1550-1800 (2003), 233-54.

Wilks, Timothy. "Art Collecting at the English Court from the Death of Henry, Prince of Wales, to the Death of Anne of Denmark." Journal of the History of Collections 9.1 (1997): 31-48.

Wood, Christopher S. Albrecht Altdorfer and the Origins of Landscape. London, 1993.

The Works of Michael Drayton. Ed. J. William Hebel, Kathleen Tillotson, and Bernard H. Newdigate. 4 vols. Oxford, 1931-41.

Zanker, Graham. "Enargeia in the Ancient Criticism of Poetry." Reinisches Museum 124 (1981): 297-311. 